\title{
TEORIA DA HARMONIA EM PLATÃO
}

\author{
RICARDO RIZEK* \\ Curso de Música \\ da Faculdade de Arte Alcântara Machado
}

\begin{abstract}
RESUMO: Estudam-se alguns casos da teoria da harmonia em Platão. Para tal, consideram-se a concepção e a terminologia musical que Platão, a um tempo só, recebe dos pitagóricos e, daí, lega a tantos quantos escreveram sobre música em grego, como Proclo, ou em latim, como Boécio. Assim, aponta-se, em Timeu 35 a - 36 d, a analogia entre autó e média harmônica; héteron e média aritmética; a ousía intermediária e a média geométrica. Daí, o modo como a "essência" intermediária viabiliza a harmonização do "outro" como "mesmo" compara-se ao modo como a média geométrica conjuga as outras médias numa série numérica cujos intervalos correspodem aos da escala musical pitagórica. Assim, das "partes" em que "deus" divide o "todo", as que estão uma para outra assim como 4 para 3 correspondem à diatessáron ou $4^{a}$ justa [m. harmônica]; as que estão uma para outra assim como 3 para 2, à diapénte ou $5^{5}$ justa [m. aritmética]. A proporção de 256 para 243 desponta, então, como a razão correspondente ao leîmma, isto é, à díesis ou "semitom" pitagórico.
\end{abstract}

PALAVRAS-CHAVE: médias geométrica, harmônica e aritmética; escalas pitagórica e ptolemaica; enkýklios paideía e quadriuium; Timeu; Platão; pitagorismo e neoplatonismo.

\section{Introdução: a música tríplice}

Falar da teoria da harmonia em Platão pressupõe redimensionar ampla e profundamente o conceito de música. De fato, pressupõe extrapolar o orbe restrito à elaboração poético-sonora da prática da arte musical, a música prática - a qual, por articular harmonias audíveis, está vinculada ao âmbito da denominada, pela musicologia tradicional, música orgânica ou instrumental -, a fim de inseri-la no sistema triádico no qual figura ao lado da música mundana e da 
humana ${ }^{1}$. Tal sistema, criado pelos antigos e compilado por Boécio (Godwin, 1990, p. 86-8), manteve-se relativamente intacto, salvo justificadas e pequenas adaptações de autores e épocas, juntamente com o quadro total da terminologia da ciência da harmonia, até o séc XVII. Declaramos necessário este redimensionamento porque é, de certa forma, muito recente, na história ocidental, a restrição do referido conceito ao que se passou a entender, na modernidade, como exclusivamente pertinente à arte musical, exatamente a mencionada acima como instrumental. Uma vez que tal restrição está, já por alguns poucos mas significativos séculos, marcantemente enraizada na consensual mentalidade geral, hoje, mesmo em certos meios mais intelectualizados, conceitos como musicalidade e harmonia têm uma amplitude que, desde o séc. XVIII, no máximo se estendem à arte em geral e, por este caminho, à estética (Palisca, 1961, p. 91-137).

Dessa forma, esta nossa conclamação a um redimensionamento do conceito de música não passa de uma recordação de um antigo elo de arte e a ciência da harmonia, uma ciência, mais que cosmológica, verdadeiramente cosmogônica, uma vez que, vale repetir, por mais de dois milênios, ou seja, dos protocosmólogos ocidentais, os pitagóricos pré-platônicos, até Kepler, talvez o último representante da cosmologia tradicional, a música instrumental integrava o referido sistema triádico ao lado da música cósmica ou mundana (macrocósmica) e da música humana (microcósmica) ${ }^{2}$.

O reestabelecimento mnemônico de uma concepção tripla de música é, ao mesmo tempo, o do vínculo hierárquico primordial que subsidiava o trânsito bidirecional entre teoria e prática, entre contemplação e técnica, entre alétheia e poíesis, entre verdade e produção de verdades ou verossimilhanças, dentre outras analogias possíveis.

Tal tripartição da música cremos que seja um dos fundamentos da construção e daí da leitura da República. Neste diálogo, a justiça, conceito mais que perfeitamente análogo à harmonia, começa por ser apresentada de uma forma exterior, perdida na problemática ideologização da dóxa, pendularmente oscilando desde a reprodução mecânica de ditos poéticos até o próprio questionamento de seu valor intrínseco, chegando até mesmo a ser tiranicamente reduzida a uma tecnicalidade jurídica. Depois, no gradual transcorrer do diálogo, é lentamente transmutada em um projeto a ser realizado dentro do homem, um projeto autoinstanciado no seio da evolução dramática das três personagens principais Sócrates, Gláucon e Adimanto - as quais, tanto sob o ponto de vista dos respec- 
tivos conteúdos quanto da forma estilística de suas interlocuções, representam tipologicamente as três camadas hierarquizadas da alma humana. Paralelamente à ascenção e declínio do Estado (Brumbaugh, 1989, pp 21, 23, 43), movimento duplo organicamente integrante da dialética platônica, a referida evolução caminha da discordância das posições das personagens para uma harmônica conversa de amigos.

Um dos marcos iniciais deste processo dá-se através da questão da temperança - virtude que está para a ética assim como o temperamento para a teoria da afinação -, conceito aplicado explicitamente por Platão exatamente na discussão sobre a música no livro III. O objetivo último de tal discussão, por um lado, é, no seio da absolutamente inevitável derrocada da cidade ideal - matematicamente prevista por Sócrates (República 546 a-d) -, atenuar, dentro do possível, a inexorável incomensurabilidade das potências internas ao som, ao homem e ao cosmos, incomensurabilidade que constitui a primeira e derradeira razão de ser de todo inescapável "des-astre". Por outro, é uma forma especial de "militância cósmica" que vê, na irredutível subjacente imperfeição dos interstícios do universo manifesto, exatamente aquele campo flexível passível de ser temperado, de ser aperfeiçoado e de, axiológica e teleologicamente, apontar para uma última perfeição, sempre prometida enquanto realizada e realizada enquanto almejada. Com a questão da justiça percorrendo, por analogias, as suas homologias no som, homem, sociedade e cosmos, Platão peregrina a descrição dialética de seus fundamentos harmônicos e desarmônicos, suas consonâncias e irredutíveis dissonâncias, para culminar, no livro X, com a exposição contemplativa da justiça cósmica através de um conjunto de escalas de cores, planetas, velocidades orbitais e tons retratados pela harmonia celeste cantada pelas Sereias, harmonia esta em perpétuo aperfeiçoamento e temperamento pela reafinação constante efetivada pelas Parcas.

Embora este roteiro, fundamentado na principialidade das estruturas tripartites, seja um dos primeiros possíveis para a leitura da República, obra fundamental para o estudo da teoria da harmonia em Platão, este artigo terá a oportunidade de percorrer, talvez não mais do que apontar, alguns outros, apoiados em outras formas de divisões perfeitamente entendíveis como decorrentes da primeira. Tais oportunidades despontarão dos comentários advindos da análise harmônica daquele momento platônico que elegemos como a base da estruturação corpórea deste artigo, a saber, o início do passo da criação da alma do mundo do Timeu, talvez o passo mais pungente de toda a ciência tradicional da 
harmonia, diálogo este cuja fortuna crítica e filosófica se deve à tradução comentada de Calcídio, graças à qual a Idade Média latina herdou a teoria da harmonia da antiguidade ocidental. Dessa forma, em sua organização geral, este artigo será pontuado pelo encadeamento intermitente das citações sucessivas do início deste passo; tal intermitência, por sua vez, será determinada pelo contraponto de comentários e apontamentos sobre o trecho em questão. Como o Timeu é o mais pitagórico dos diálogos platônicos, torna-se difícil, por vezes, distinguir, especialmente no âmbito da teoria harmônica, as perspectivas dos pitagóricos e dos platônicos, e Aristóteles serviu-nos para apontar a identidade e as diferenças entre elas. Por ser o Timeu, como dissemos, o diálogo mais comentado de Platão, dentro de um verdadeiro oceano de comentadores, escolhemos os comentários de Proclo como o núcleo temático dos contrapontos elucidativos das citações do referido passo, escolha justificável tanto qualitativamente, dada sua inquestionável autoridade, quanto por se tratar do mais extenso comentário herdado pela tradição ocidental.

Encerramos esta introdução com uma importante ressalva para o leitor não acostumado com os ditames da teoria da harmonia. Foi, por vezes, impossível não antecipar breves explanações sobre conceitos que, dada a rítmica das citações do passo do Timeu, só mais tarde viriam a ser um pouco mais definidos e explicados, sempre dentro das limitações inerentes a um artigo. Esperamos que, frente a este justificável obstáculo, a leitura não seja interrompida e, pela mobilização de sua paciência, que o leitor, afortunadamente para nós, nela prossiga, permitindo assim o despontar das indispensáveis explicações.

\section{Peîras e Apeíron}

Observemos um pequeno momento inicial do famoso relato de Timeu:

[Deus formou], da substância indivisível, que se comporta sempre de maneira invariável, e da substância divisível, que é gerada nos corpos, entre as duas, misturando-as, uma terceira espécie de substância intermediária, compreendendo a natureza do mesmo e a do outro. E assim formou-a entre o elemento indivisível dessas duas realidades e a substância divisível dos corpos. Depois tomou essas três substâncias e combinou-as em uma única forma, harmonizan- 
do à força com o mesmo a substância do outro, que se deixava a custo misturar. Misturou as duas primeiras com a terceira, e das três fez uma só. Em seguida, a esse todo dividiu em número conveniente de porções, cada uma composta pelo mesmo, o outro e esta terceira (35a-d).

No plano ontologicamente antecedendente à ação criacional de deus, indivisibilidade e divisibilidade, sem a mediação da terceira substância, mantêm-se como princípios inconciliáveis. A divisibilidade é claramente localizada nos corpos, e tal menção da corporeidade enseja que, ao lado da estrutura tripartite das três substâncias na ante-sala da criação da alma, uma outra, também tripla, tenha como termos extremos, inconciliáveis em si mesmos, o noûs e o sôma, termos cuja mediação é feita pela própria instância que está sendo criada, a psykhé.

É pela correspondência destas duas estruturas tripartites que podemos também localizar o plano da referida indivisibilidade, pois, como há um deus que pode operar sobre ela, sua monadicidade não poderia ser absolutamente divina, estando, portanto, já no plano intelectivo. Se tal indivisibilidade é intelectiva, e a divisibilidade é corpórea, então, na medida em que a alma terá sua estrutura tripartite advinda da conciliação antecedente realizada na terceira substância, esta última corresponde à alma, a infinita inteligibilidade, na antesala de sua própria criação. Como a tripartição da alma define a esquemática de uma tripla participação, ela, além do indivisível noûs e do somático indefinidamente divisível, participa de si mesma em si mesma através de sua participação na terceira substância, substância esta que lhe comunica as outras duas na forma de mesmidade e de alteridade (ou de identidade e diferença), formas imanentes à terceira substância (e portanto à alma) dos princípios transcendentes da indivisibilidade e da divisibilidade, e comunica a propriedade de si mesma na forma de essencialidade.

Segundo Proclo, a alma, enquanto todo que anima o universo, este último o todo de todas totalidades, é um todo que antecede a própria possibilidade de divisões, mas também é tanto um todo propenso a dividir-se e dissipar-se em suas partes como um todo em cada uma de suas partes (Proclus, 1990, p. 75-6). A garantia desta totalidade tripla está no entrelaçamento dos três componentes da alma, a saber, a essencialidade advinda da substância intermediária (substância que intermedeia a indivisibilidade e a divisibilidade) e um novo par novamente 
incompatível, a mesmidade e a alteridade (naturezas compreendidas na terceira substância), que "pressionam a alma entre a posse simultânea de sua primordial unidade e da multiplicidade que ela experimenta no mundo do tempo, do espaço e das criaturas separadas", como nos explica uma nota de Godwin sobre este preciso momento (Godwin, 1990, pp. 403-4).

Platão estabelece que, através deste estágio inicial de modelagem divina, modelagem que efetivamente começa pela forja da terceira substância, a alma é uma entidade paradoxal. Ela é um campo de atrito entre duas instâncias inconciliáveis, das quais participa e, pela participação na terceira substância, tem como função, já no plano propriamente anímico, harmonicamente unir. Proclo, seguindo a tradição pitagórica, vê os princípios da indivisibilidade e da divisibilidade respectivamente como o monádico e o diádico. "A alma, contudo, por ser uma média entre o noûs e o corpo, é, ao mesmo tempo, uma mônada e uma díada" (Proclus, 1990, p. 76), ela é o hén-dyás participando igualmente do limite, que é indivisível, e da infinidade, termo que, no contexto pitagórico e platônico, deve ser entendido como o ilimitado, ou seja, como a divisibilidade ad infinitum.

Limite e Ilimitado, peîras e apeíron, eis os dois princípios mais básicos da cosmologia pitagórica que Platão repropõe com os conceitos de indivisibilidade e divisibilidade, princípios em si mesmos inconciliáveis que antecedem a aproximação demiurgicamente efetivada pela conciliação da terceira substância, a qual compreende, por esta conciliação, a estrutura da participação da alma nestes dois princípios através do mesmo e do outro.

Aristóteles, na Metafísica (i 5986 a 23), transmitiu-nos as dez digressões polares que partem da polaridade principial de peîras e apeíron, designadas no momento do Timeu que estamos comentando com os conceitos de indivisibilidade e divisibilidade e, a seguir, com os de mesmidade e alteridade ${ }^{3}$. Na seqüência deste mesmo passo assim ele continua: "Os pitagóricos identificam o Ilimitado com o Par. Pois este, eles dizem, quando circundado e limitado pelo Ímpar, provê as coisas com o elemento da Ilimitação". Dando continuidade a esta afirmação, Aristóteles dá como exemplo dois tipos de expansão gnomônica: se gnómones são colocados ao redor da unidade, pitagoricamente representada por um ponto, a figura resultante é sempre um, ou seja, sempre e invariavelmente a mesma; se, pelo contrário, gnómones partem de qualquer quantidade que não a unidade como é o caso exemplar de 2, pitagoricamente representado por dois pontos -, então, a figura resultante é sempre outra (Guthrie, 1987, p. 301-2). Fideler (Guthrie, 1987, p. 23) elucida-nos que Aristóteles está aludindo às figuras de fig. 1 e 2. 


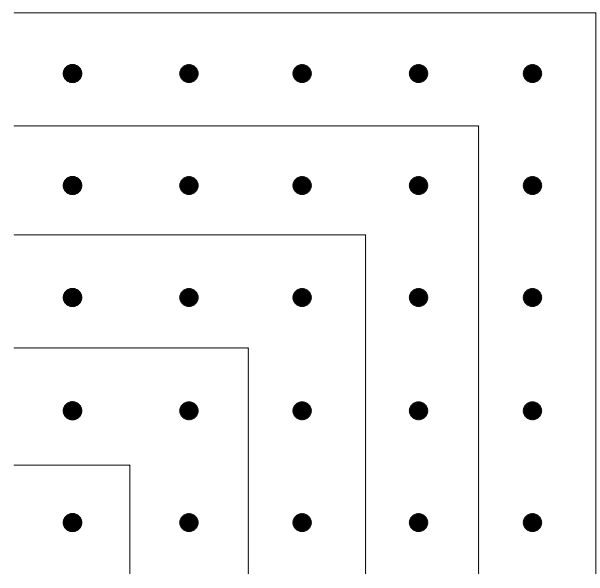

fig. 1

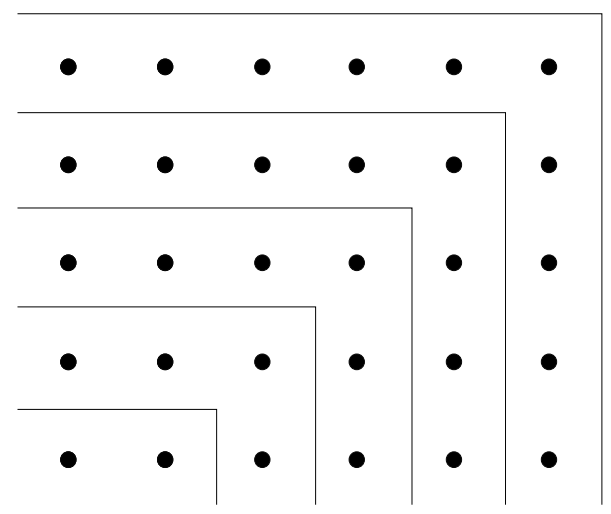

fig. 2

Ora, uma dentre as dez oposições advindas de peîras e apeíron é, respectivamente a estes dois princípios, a de quadrado e retângulo. $\mathrm{Na}$ fig. 1, a expansão gnomônica dá-se através do crescimento de conjuntos de pontos que representam os números ímpares - 1,3,5,7,9 -, resultando em quadrados que caracterizam as razões de igualdade que são sempre a mesma - 1:1, 2:2, 3:3, 4:4 e 5:5 -, em suma, a própria unidade, só que transposta de sua absolutez para o plano relacional da igualdade. $\mathrm{Na}$ fig. 2, a expansão gnomônica dá-se pelos números pares - 2,4,6,8,10 -, resultando em retângulos que, logo após o primeiro - que 
está na razão dupla de 2:1, razão que, para além ou aquém de caracterizar um retângulo, é também e fundamentalmente um quadrado duplo, ou seja, um eqüíssono ou oitava -, caracterizam razões de maior desigualdade (ou, conforme o sentido de leitura, suas recíprocas de menor desigualdade) - (2:1), 3:2, 4:3, 5:4 e 6:5 - que são sempre diferentes, conceito antologicamente identificado com a alteridade. Aristóteles, portanto, oferece-nos uma das mais clássicas exemplificações da mesmidade e da alteridade no âmbito pitagórico dos números figurados, vale dizer, da geometria.

Platão diagnostica que duas coisas, sozinhas, não podem satisfatoriamente ser unidas sem uma terceira, "pois é preciso que no meio de ambas haja alguma ligação que as aproxime" (Timeu $31 \mathrm{c}$ ). Embora estabelecida entre a existência unitária de deus e a existência múltipla do cosmos, a mediação é o princípio fundamental (que percorre os orbes divino, natural e humano) da ciência da harmonia, procedimento cuja validez se mantém intacta até mesmo dentro da dimensão poético-sonora da arte discursiva musical, ou seja, em sua concepção como elaboração artesanal, o que, segundo Edward Lippman, demonstra uma proximidade possível entre a perspectiva tradicional da música enquanto uma disciplina matemática e a teoria específica da arte (Lippman, 1975, p. 17). Claro que, perante a capacidade humanamente divina e divinamente humana de testemunhar este princípio harmônico nos diversos mundos, a plenitude de tal testemunho, como o próprio diálogo platônico indica segundo Proclo, está em libertar-se do sensível, efetivando a transposição das imagens aos paradigmas e, assim, elevando-se ao plano da harmonia imaterial e essencial (Proclus, 1990, p. 75).

\section{Herança e Transfiguração Platônica do Pitagorismo}

Há semelhanças e significativas diferenças entre o pitagorismo e o platonismo. Aristóteles, na Metafísica (987 b 10), sintetiza o maior ponto de semelhança, para alguns a identidade, entre os dois: "Platão somente mudou o nome, pois os pitagóricos dizem que as coisas existem por imitação dos números, enquanto que Platão, por participação". Estes conceitos, imitação e participação, implicam uma perspectiva metafísica. Mas se Aristóteles sintetizou a semelhança, também expressou sinteticamente a cabal diferença:

Em harmonia com eles [os pitagóricos], ele [Platão] afirma que os números são os princípios de ser para outras coisas. Mas é peculiar 
a ele, ao invés de um único Indefinido [como entendiam os pitagóricos], postular a existência de um duplo, um Infinito do grande e do pequeno; e é também peculiar que ele separa os números das coisas visíveis, enquanto eles dizem que os números são as próprias coisas e não interpõem objetos matemáticos entre elas [grifos nossos] (Metafísica i 6; 987 b 22).

Podemos, então, observar que as doutrinas da imitação e da participação se diferenciam como duas perspectivas metafísicas, pois a primeira constitui uma metafísica da imanência, enquanto a segunda, uma metafísica da transcendência (Fideler, 1988, pp 34-5). De forma que Platão é simultaneamente herdeiro e transfigurador da tradição pitagórica, uma vez que os pitagóricos, juntamente com os físicos pré-socráticos, são perì phýseos, ou seja, "a-bordam" a natureza em uma plena suficiência sobrenatural, dado que tal concepção de phýsisé, de per si, metafísica. Claro que, em distinção da física jônica, os pitagóricos são os constituidores de uma verdadeira filosofia de macrossistemas fundamentada nas matemáticas. Porém, exatamente porque os números são as coisas, e porque eles não interpõem objetos matemáticos entre elas, o estudo da matemática não é uma preparação, como no caso de Platão, para a contemplação da realidade eidéticonoética, mas o contacto direto com tal realidade em sua imanência no cosmos.

MacClain afirma que, dada a própria simplicidade da teoria da afinação, esta ciência, em comunhão com a base empírica dada pelo monocórdio, foi a primeira, dentro da Física, a tornar-se plenamente matematizada (MacClain, 1984, p. 3-4). Platão dá evidências inquestionáveis de ter conhecido o monocórdio - um aparato técnico destinado a manter constante todos os outros fatores enquanto somente o comprimento da corda é variado -, o que fica claro, por exemplo, na passagem onde ironicamente ele brinca com os músicos que não se libertam da prisão sensível determinada pelo apego a este instrumento: "[esses músicos virtuosos] agregam dificuldades às cordas e inclusive torturam-nas, valendo-se do tormento das cravelhas" (República 531 b)5.

Contudo, mesmo perante o imprescindível meio matematizado de tal estudo, a finalidade última deste não poderia deter-se na matemática. Pois se, segundo Proclo, libertar-se do sensível, realizando a transposição das imagens para os paradigmas, é o passo inicial que nos leva da empiria para o estudo matemático, também passa a ser imprescindível um passo que transponha a inexorabilidade destes meios para aquela que seria a finalidade inerente a eles (Proclus, 1990, p. 75). Esta outra transposição é, nos termos do passo 341 c-d da Sétima Carta de Platão, a de uma auto-transfiguração pela qual a finalidade última destes estudos 
preparatórios, por um salto excelência, passa, subitamente, a habitar na própria alma humana ${ }^{6}$.

\section{Atetraktýs}

Para qualquer das duas perspectivas metafísicas, a realidade subdivide-se em indefinidas camadas verticais as quais, dentro da faixa freqüencial da apetência decodificadora humana, mantêm uma correspondência com os órgãos e faculdades do homem - um dos temas de destaque na maior e mais completa obra pitagórica que o adentra, a saber, o Timeu de Platão -, o que significa que tais camadas são macro e microcósmicas. Perante a reconhecida infinidade destes planos externos e internos, os pitagóricos, herdeiros e transmissores de uma vertente tradicional da qual Platão - especialmente o Platão pitagórico - ocupa o papel mais decisivo, serviam-se de uma viva imagem simbólica da totalidade, um verdadeiro paradigma de síntese do todo, a tetraktýs, a qual eles reverenciavam como a lei máxima da imanência da divindade no cosmos. Como prova disto, basta a recordação do famoso juramento pitagórico, juramento que todos os neófitos, a partir de um certo estágio iniciático, faziam: "Eu juro pela descoberta da Tetraktýs / Que é a nascente de toda nossa sabedoria / A fonte perene e a raiz da Natureza" (Fideler, 1987, p. 28).

A tetraktýs, como símbolo vivo da imanência divina no cosmos, é tal imanência e sua percepção ao mesmo tempo; ela é o salto de excelência pelo qual o número pode ser tomado como paradigma. Este paradigma tem a capacidade de "ler" o padrão da orgânica quadruplicidade como um genótipo que se desvela enquanto se oculta em diferentes fenótipos, ou melhor, em diferentes classes de fenômenos. Como nessas matrizes fenomênicas - tais como, por exemplo, a dos elementos (fogo, ar, água e terra) e a do espaço (ponto, linha, plano e sólido) podemos encontrar o mesmo padrão de quadruplicidade na articulação dos quatro níveis em cada uma delas, é possível, desta forma, perceber um modelo analógico, ou uma similar proporcionalidade, de uma determinada camada de uma das cadeias quádruplas com a sua posicionalmente correspondente no outro encadeamento. Tal procedimento é perfeitamente estensível a todas as tetraktýes referentes às diversificadas matrizes de fenômenos. Assim, teríamos faixas freqüenciais de analogias interrelacionando, no nosso delimitado exemplo, fogo e ponto, ar e linha, etc., com as medidas qualitativas, propriamente harmônicas, 
das passagens críticas, ou intervalos, de um plano a outro, o que torna evidente que, sob muitos aspectos, a filosofia pitagórica já é, tal como sua herdeira platônica, uma filosofia de analogias.

Não é difícil perceber que o próprio quadrivium (conjunto articulado de quatro ciências que tem a música como uma de suas integrantes) é uma tetraktýs, análoga, enquanto tal, a todas as outras. Assim, o caráter pontual da quantidade discreta tomada em si mesma e a principialidade motívica do número fazem com que a aritmética corresponda ao ponto e ao fogo. A quantidade discreta tomada em relação com outra, relação que outra coisa não é senão uma razão ou intervalo, faz com que a música corresponda à linha e ao ar - sendo que a primeira é a conexão de dois pontos, e o segundo, o meio pelo qual a emissão ígnea, como um centro, encontra difusão radial e radiosa. Já a quantidade contínua imóvel, na ótica da geometria plana, relaciona-se, obviamente, com a superfície e com a água, base reflexiva inferior da radiosidade aérea. A quantidade contínua móvel, na ótica da estereometria e da astronomia, relaciona-se com o volume e a terra, ou seja, com os corpos celestes e terrestres.

É na perspectiva da tetraktýs que Brumbaugh diagonostica um roteiro de estudo das matemáticas subjacente à estrutura da República, roteiro estruturado em seis níveis: 1 . um número e seus fatores, no livro I (aritmética ${ }^{7} ; 2$. a escala e a temperança - e portanto o temperamento -, no livro III (música); 3. a linha e os níveis de conhecimento, no livro VI; 4. um triângulo, elaborado dentro de um sólido, mapeando os sucessivos estágios no declínio do Estado, no livro VIII (geometria); 5. um sólido, um cubo, construído a partir de uma base plana quadrada, no livro IX (estereometria); 6. um modelo astronômico, com propriedades postas em equilíbrio para evidenciar a justiça cósmica, que culmina com as Sereias das órbitas planetárias cantando em harmonia, no livro X (astronomia) (Brumbaugh, 1989, p. 43).

\section{As Sete Porções e a Lámbda Platônica}

Principiou a divisão como se segue. Primeiramente, separou do misto total uma porção. Tomou depois uma porção dupla desta e uma porção igual a uma vez e meia a segunda e a três vezes a primeira; uma quarta, o dobro da segunda; uma quinta, tripla da terceira; uma sexta, oito vezes a primeira; uma sétima, vinte e sete vezes a primeira (Timeu $35 \mathrm{~b}-\mathrm{c}$ ). 
Dentro deste conjunto de estágios pelos quais deus engendra as sucessivas partições, não é difícil perceber que as quatro primeiras se destacam. A primeira porção porque é o 1, que representa a base fundamental na qual todas as outras porções estarão referidas. Tal unidade poderia ser expressa pela razão de igualdade de 1:1 (uníssono), uma vez que, não sendo nem o um divino (absolutamente monádico) nem o um intelectivo (que é mais um do que múltiplo), é o um no plano da alma, que é simultaneamente um e múltiplo, plano que antecede o um corpóreo, que é mais múltiplo do que um. A segunda porção, duas vezes a primeira, estabelece a razão dupla de 2:1 (eqüíssono), a oitava justa ou a diapasôn, e, ao inaugurar a progressão geométrica dos duplos, inaugura prototipicamente todas as progressões que partem e se distanciam da unidade. A terceira destacase porque é a primeira aproximação entre a primeira e a segunda, pois 3 , quando medido pela segunda porção, é $2+1$, uma vez e meia a segunda porção, ou seja, 3:2, a média aritmética de 1 e 2 enquanto extremos, a quinta justa ou a diapénte; quando medido pela unidade é $1+1+1$, três vezes a primeira, $3 \times 1$, ou seja, $3: 1$, a décima segunda justa ou a diapasôn mais a diapénte, inaugurando a progressão dos triplos. E finalmente a quarta, que, sendo 4 , por ser o primeiro número quadrado ou plano, estabelece o nível propriamente anímico da alma, definindo o campo incorpóreo da idealidade da manifestação, ou seja, a dupla oitava ou a dis diapasôn, e que, quando é medida pela segunda, 2, reproduz uma segunda oitava pela razão dupla $4: 2$, que, por transpor a oitava primordial (2:1), permite que a média aritmética se expresse pelo número inteiro 3.

Podemos então antecipar uma conclusão da ciência da harmonia, tanto à luz da instância puramente matemática quanto da base empírica dada pelo monocórdio, sobre os quatro primeiros termos de uma progressão harmônica, correspondentes às alturas de sons da totalidade de uma corda musical, de sua divisão ao meio, de sua tripartição e quadripartição. Tais divisões $(1 / 2,1 / 3,1 / 4)$, que partem da totalidade da corda (1), geram alturas de razões recíprocas: o uníssono (1:1, o som fundamental produzido pelo tangimento da totalidade da corda); o eqüíssono ou a diapasôn ( $2: 1$, o intervalo de razão dupla, a oitava do som fundamental, gerado pela divisão ao meio da corda); a diapasôn mais a diapénte, ou a oitava acrescida de uma quinta justa (3:1, o intervalo de razão tripla gerado pelo tangimento da terça parte da tripartição da corda); a dis diapasôn (4:1, a dupla oitava, razão quádrupla produzida por um quarto da corda), que abarca todas as razões anteriores.

A importância da proporção geométrica neste encadeamento é auto-evidente, pois cada altura sonora é uma multiplicação que incide sobre o primeiro 
termo, a unidade, dentro do campo do quaternário advindo da progressão dupla (1:2:4). Esta proporção é a primeira a permear o encadeamento dos termos em questão, referindo-os cada um à unidade. A partir dela despontam as duas proporções restantes, a aritmética, pela média aritmética da razão 3:2 (a diapénte ou quinta justa dentro da primeira oitava), e a harmônica, pela média harmônica da razão 4:3, a diatessáron ou quarta justa dentro da mesma oitava. A ordenação final do entrelaçamento das três proporções dentro dos quatro termos é, então, 1:2:3:4, no qual cada termo mede os que o ladeiam e é medido por estes.

Tal ordenação, enfatizada no passo platônico pelo dimensionamento da terceira porção como uma vez e meia a segunda, faz surgir, a partir das razões múltiplas (as alturas sonoras) e suas recíprocas submúltiplas (as partições da corda), uma outra categoria de razões, as superparticulares. Estas são razões de maior desigualdade pelas quais um número maior compreende inteiramente um outro menor, mais a menor parte deste, ou seja, a unidade (1). $O$ primeiro exemplo deste tipo de razão é exatamente a média aritmética dentro da oitava, 3:2 ou um acrescido de sua metade. Temos, dentro da harmonia proveniente das quatro divisões demiúrgicas primordiais, mais um termo, além de 3:2, da seqüência das razões superparticulares: 4:3 ou um acrescido de sua terça parte, a média harmônica dentro da oitava. Assim, a totalidade deste primeiro conjunto de concordâncias primordiais dentro do âmbito do quaternário é composta dos intervalos de uníssono (1:1), oitava (2:1), quinta justa (3:2) e quarta justa (4:3), conjunto este que é uma tetraktýs das consonâncias perfeitas.

Como a própria expansão gnomônica de retângulos, que apontamos a propósito de Aristóteles, demonstra (fig. 2), a primeira extrapolação do âmbito principial do quaternário dá-se deste para o do senário. Uma vez que a proporção geométrica, representada pelo número 2 (a média geométrica dos extremos 1 e 4), preestabelece o quaternário dentro do âmbito geral de uma dupla oitava, é o número primo 3 que articula, como um número inteiro, as duas mediedades que se espelham uma à outra: 3:2, a média aritmética, e 4:3, a sua recíproca, a média harmônica. Já no âmbito do senário é o número primo 5 que articula, como um número inteiro, as duas razões superparticulares que, pela expansão gnomônica de retângulos a partir do quadrado duplo ou retângulo de 2:1, despontam como concordâncias imperfeitas: 5:4, um e um quarto, a terça maior, e 6:5, um e um quinto, a terça menor ${ }^{8}$.

Segundo Proclo, o demiurgo "divide a alma em partes, harmoniza as partes divididas, e torna-as concordantes [consonantes] umas com as outras". Dada 
a dimensão teológica de sua exegese, ele entende estas operações respectivamente como dionisíaca e apolínea.

Pois dividir e produzir todos nas partes e presidir sobre a distribuição de formas é dionisíaco; mas perfazer todas as coisas harmonicamente é apolíneo. Portanto, como o demiurgo compreende em si mesmo a causa destes dois deuses, ele divide e harmoniza a alma (Proclus, 1990, p. 77) $)^{9}$.

Se colocamos, sinteticamente e na mesma ordem proposta por Platão, os números envoltos na seqüência de partições do Timeu, temos então 1, 2, 3, 4, 9 , 8 e 27 . Não é difícil perceber que se trata de um entrelaçamento dos termos de um encadeamento geométrico de duplos e triplos, ambos partindo da unidade, onde os quadrados e cubos de 2 e 3 - números que o pitagorismo entendia configurar a primeira fêmea e o primeiro macho - são distendidos nas três dimensões necessárias para formar um cosmos espacial, ou seja, visível e tangível.

Há o plano em que o um é unidade absoluta, pois, como afirma Proclo, "o um dos deuses é unicamente um". Distintamente de tal plano, o um do noûs é mais um que múltiplo. Já nos dois planos descensionalmente subseqüentes a este último, o um da alma é similarmente um e múltiplo, enquanto que o um do corpo é mais múltiplo que um. Se o um da alma é o intelectível monádico nesta, a segunda parte, o 2, duas vezes a primeira, gerando todas as progressões, é a díada indefinida e a infinidade inteligível na alma. A terceira parte, o 3, por ser efetivamente o primeiro número e por manter-se voltado para a unidade, converte toda a alma para seu princípio, conversão que para Proclo é uma função triádica, e é por isso que este, atentamente resgatando as palavras de Platão, afirma que a terceira parte é medida plenamente pela primeira (3:1), porém apenas parcialmente pela segunda (3:2).

A quarta e quinta porções, respectivamente 4 e 9 , evidenciam o plano da alma que corresponde propriamente à alma, ou seja, que a alma governa peculiarmente as naturezas secundárias, pois, como são números planos e quadrados, são as causas intelectuais dos correspondentes incorpóreos que antecedem o que está dividido nos corpos. A quarta parte, 4, por ser o quadrado da segunda parte, 2 , é a causa da progressão e da geração, dando a esta parte, a quarta, uma direção descensional, enquanto que a quinta parte, 9 , por ser o quadrado da terceira, 3 (a conversão intelectual), é causa da conversão e da perfeição, dando a esta parte uma direção ascensional (Proclus, 1990, p. 83). E da mesma forma 
que a medição da terceira porção pela segunda colocou em cena o primeiro superparticular, pois 3 é 3:2 de $2(3: 2 \times 2=3)$, a quinta porção, 9, dista intervalarmente da quarta, 4 , em 9:4 desta última $(9: 4 \times 4=9)$, ou seja, a distância de duas quintas justas ou diapénte, $3: 2 \times 3: 2$ ou $(3: 2)^{2}$.

A sexta e sétima porções, 8 e 27 , por serem números sólidos, contêm em si mesmas as causas primordiais dos corpos e das massas sólidas. 8 é a tripla oitava, $2^{3}$, ou o dobro do dobro do dobro da unidade; 27 é o triplo do triplo do triplo, $3^{3}$, número cúbico que, como já apontamos acima, juntamente com o anterior, encaminha o concrescionamento da ordena-ção divina em direção ao visível e tangível. Quando medido pela porção anterior, 8, resulta em 27:8, a medida de três diapénte, ou seja, 9:4 × 3:2, ou (3:2)3. Enquanto números sólidos, a sexta parte (8) tem proveniência na segunda, e a sétima na terceira, pois 8 é o cubo de 2, tal como 27 é de 3, mas, no texto platônico, ambas estão referidas exclusivamente pela primeira porção, o que não escapou do olhar atento de Proclo. Segundo este herdeiro da tradição platônica, Platão quereria destacar a conversão das duas últimas para a primeira, conversão que é a das terminações inferiores da alma ao seu cume primordial (Proclus, 1990, p. 83).

Esta série que combina os duplos e os triplos em uma tetraktýs posta em evidência pela descrição feita nos parágrafos anteriores, e que é uma referência às "três distâncias e quatro limites" mencionados na República 546, encontrou plena representação visual em uma figura denominada pela tradição a Lámbda platônica, dada a sua forma, e cujos registros a datam pelo menos a partir do século de Platão.

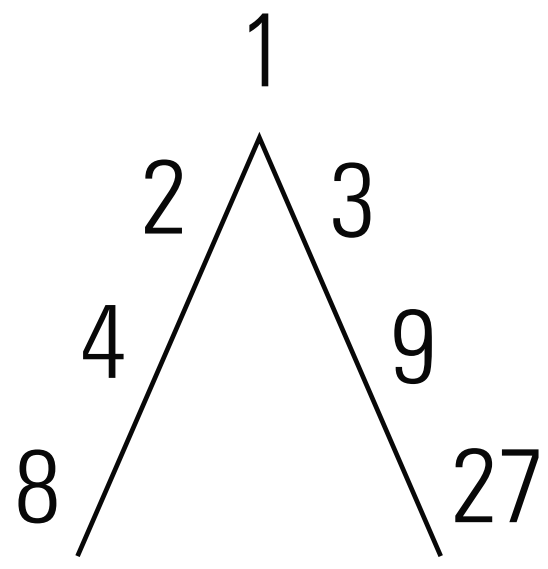

fig. 3 
Antes de mais nada é preciso apontar que, no seio das partições da alma, a progressão geométrica constituída de triplos, e portanto de números ímpares, representa a participação daquela no noûs, ou seja, no espírito, enquanto que a progressão geométrica constituída de duplos, a participação nos corpos. Esta configuração é musicalmente perfeita, pois em se tratando de duas linhas-pilastra, que reúnem, em cada uma respectivamente, a seqüência em progressão geométrica dos duplos e triplos, então, mais duas linhas de força, internas às e nascidas das duas anteriores, podem ser inferidas, com cada uma destas pondo em seqüência, desde o seu ponto de vista, a combinação de razões compostas de um duplo e de um triplo. Assim, no ponto descensional onde a unidade é, por um lado, multiplicada por 2 e, pelo outro, por 3, a dupla direção de leitura, pela qual cada um destes números mede o outro, dar-nos-ia duas articulações de razões recíprocas: a de menor desigualdade 2:3, e a de maior desigualdade 3:2 (vide nota 8). Seguindo pelos dois próximos termos - os dois primeiros números quadrados 4 e 9 - teríamos, então, de um lado, 4:9 e, do outro, o seu recíproco 9:4. Finalmente, com os dois últimos termos, os dois primeiros números cúbicos $8 \mathrm{e}$ 27 , a razão 8:27 e sua recíproca 27:8. Como a unidade, representada pelas razões de igualdade, mantém, por uma linha vertical projetável que desce do ápice à base da lámbda, seu papel invariavelmente intermediador entre cada par destas razões recíprocas, de um duplo sobre um triplo e de um triplo sobre um duplo, o resultado final, se organizássemos todas estas razões em uma série em progressão crescente, seria este: 8:27, 4:9, 2:3, 1, 3:2, 9:4 e 27:8, uma progressão geométrica cuja constante é 3:2, e cuja média geométrica de cada extremo correspondente e portanto da seqüência inteira é 1 . Não nos esqueçamos que, em música, a medida de dois intervalos iguais se dá pela exponenciação, ou seja, pela multiplicação dele por ele mesmo. Assim sendo, a progressão acima poderia ser expressa por $(3: 2)^{\mathrm{n}}$, o que resultaria nos seguintes termos: $(3: 2)^{-3},(3: 2)^{-2},(3: 2)^{-1},(3: 2)^{0},(3: 2)^{1},(3: 2)^{2},(3: 2)^{3}$.

Embora em momento anterior tenhamos exemplificado a reciprocidade entre razões à luz da proporção inversa que se dá entre comprimento da corda e a altura do som, o leitor inexperto em música talvez já esteja em condições de entender que este espelhamento - entre as razões de maior e menor desigualdade, múltiplas e submúltiplas, etc. - também pode ser concebido dentro das alturas sonoras, ou seja, em termos puramente freqüenciais. 


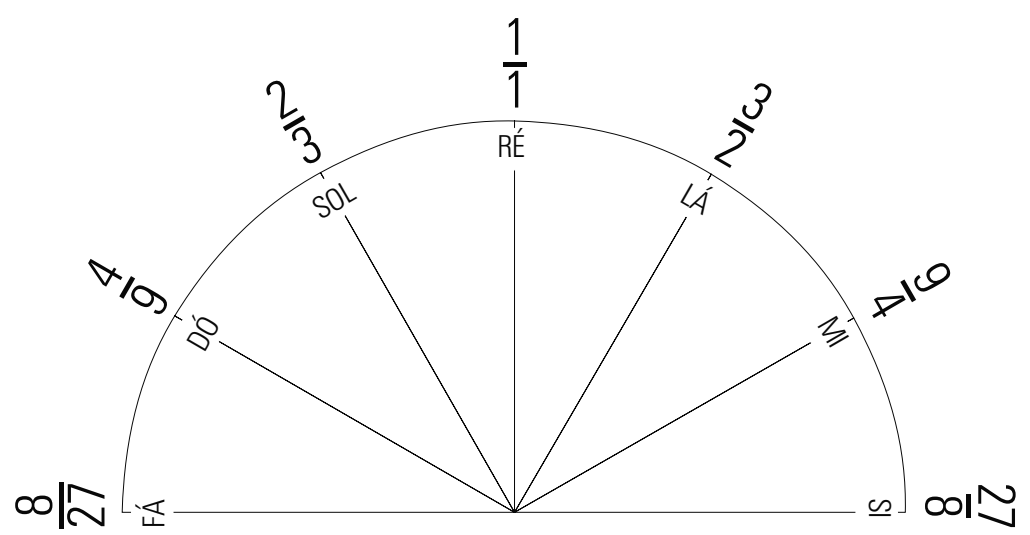

fig. 4

A visão da reciprocidade exclusivamente no âmbito das alturas de sons é, na verdade, muito simples, pois toda razão de maior desigualdade (quando, em termos fracionais, o numerador é maior que o denominador) expressa um intervalo ascendente frente a um termo referencial dado, enquanto sua recíproca, a razão de menor desigualdade (que inverte a anterior), expressa a mesma medida intervalar, só que em sentido contrário, descendentemente. De forma que, se 3:2 (1 acrescido de sua metade) é uma quinta justa, diapénte, ascendente, então 2:3, a unidade diminuída de sua terça parte (que vimos até agora como sendo o comprimento da corda que produz 3:2 do som), é, em termos puramente freqüenciais, a mesma medida intervalar, uma quinta justa, descendente. Ora, como a progressão geométrica que extraímos da lámbda platônica tem como constante 3:2, e este intervalo é o de quinta justa, então, tal progressão outra coisa não é senão um encadeamneto de quintas, há séculos denominado pela teoria musical o círculo de quintas. O que siginifica que todas as razões à esquerda da unidade referencial, 1, são quintas encadeadas descensionalmente a partir da fundamental 1, e, obviamente, as razões à direita, quintas ascensionais (fig. 4).

$\mathrm{Na}$ fig. 4, dispomos os termos do referido encadeamento de quintas - que extraímos da progressão geométrica das razões articuladas pelos pares de termos da progressão geométrica de duplos e triplos da lámbda platônica - em um semicírculo dividido em seis partes iguais por sete raios, e para cada raio colocamos uma razão ou uma nota deste segmento do círculo de quintas. Escolhemos para a fundamnetal 1 a nota ré, e o motivo de tal escolha é que, com ela, a seqüência de quintas - ascendentes à direita de ré, e descendentes à esquerda - se conforma perfeitamente ao conjunto das notas brancas do piano. 


\section{Antístrophon ou Reciprocidade}

A operação mais primordial, assentada na base empírica da utilização do monocórdio como instrumento, e sobre a qual o edifício puramente matemático da ciência da harmonia é construído, é a da divisão da corda em sua exata metade. Tal divisão reproduz o som fundamental, da corda solta e inteira, uma oitava acima, por vibrar exatamente o dobro de vezes no mesmo "espaço de tempo".

A formulação pitagórica do som enquanto altura contraposta ao tamanho da corda sustenta uma tensional relação analógica entre planos do real. De forma que a metade do comprimento da corda é o dobro da altura do som, ou, enfatizando ainda mais a reciprocidade inversa entre os mundos e generalizando esta lei para todas as alturas sonoras, que a altura do som é inversamente proporcional ao comprimento da corda.

Esta estrutura especular, a da reciprocidade inversa, fundamenta, em micro e macro-escalas, diversas obras de Platão. Sua presença destaca-se enquanto elemento-chave para a exegese da totalidade formal da República. Neste diálogo, em uma microescala, vários pequenos momentos, com um conteúdo isomorficamente conectado com a estrutura especular da totalidade da forma, poderiam ser tomados como exemplo desta reciprocidade, dentre os quais MacClain destaca um como fundamento de um rigoroso estudo dos opostos: "Algumas coisas são aptas a serem chamadas de pensamento, enquanto outras não... Aptas a serem assim chamadas são aquelas que atingem os sentidos juntamente com seus opostos" (524 d) (MacClain, 1984, p. 7).

MacClain entende que o conceito de reciprocidade cíclica é um dos maiores méritos, sob o ponto de vista da ciência da harmônia, das análises de Brumbaugh da República vista como verdadeiro curso sobre dialética, com seus nove temas maiores dispostos em dois grandes conjuntos, cada um destes correspondendo respectivamente aos movimentos ascendente e descendente (MacClain, 1984 , p. 3). O movimento ascensional, escalonando os quatro primeiros temas (a jornada da vida para a morte: L. I; os poetas e a poesia: L. II-III; a estrutura tripartite do self com a definição da justiça como harmonia na alma: L. IV; a construção do Estado: L. V-VII), culminará no quinto tema (a Justiça em si mesma ou o Bem, cujo símbolo é o sol: L. VII), o tema central que, diferenciando-se tanto dos quatro primeiros quanto da retomada especular de cada um destes pelos quatro últimos (o declínio do Estado: L. VIII-IX; a avaliação final dos tipos de alma e de vida: L. IX; o necessário exílio do mau poeta da politeía: L. $\mathrm{X}$; o poema filosófico trazido por um mensageiro que narra o retorno da alma da 
morte para a vida com o mito do Er: L. X), é o único que não será espelhado, pois, como vértice que é, é nele que recai o próprio espelho ${ }^{10}$.

Neste diálogo, contudo, o espelhamento não se dá apenas formalmente pelo resgate temático posicionado como um extremo correspondente, o que reduziria tal estrutura, muito abaixo de uma harmonia, a uma mera simetria extensista. Muito além disto, também o próprio conteúdo de cada tema resgatado é exposto na direção inversa da que havia recebido enquanto o original a ser invertido, tal como o de Céfalo contemplando a jornada da vida em direção à morte, espelhado pelo do Mito de Er, que narra a jornada da morte para a vida, ou ainda o da construção do Estado, perfeitamente espelhado pela descrição do declínio deste ${ }^{11}$.

Em um dos muitos exemplos do tipo de procedimento especular utilizado na totalidade da República, nas Leis, depois que Platão ordena escalonadamente a hierarquia dos dez movimentos, quando o décimo estágio ascensional, o da superioridade do movimento que pode mover a si mesmo, é atingido, ele coloca na boca do ateniense que "não foi muito justo classificá-lo em décimo lugar" uma vez que "a razão nos afirma que é o primeiro por nascimento e por poder" [895a]. Em palavras demasiadamente singelas poderíamos afirmar que, na duplicidade inerente à toda leitura de um encadeamento escalar - ascensional e descensional - o último degrau da subida é o primeiro da descida e vice-versa.

Pela dinâmica da reciprocidade, podemos concluir que a progressão geométrica do semicírculo em questão, além de expressável por $(3: 2)^{\text {n }}$ (ou seja, na concepção moderna de escala, um encadeamento de quintas ascendentes ou diapénte), também o seria por $(2: 3)^{\mathrm{n}}$ (encadeamento de quintas descendentes), possibilidades inerentes às duas direções de leitura, da esquerda para a direita e vice-versa, pois, por exemplo, $(3: 2)^{-1}=2: 3$, e, obviamente $(2: 3)^{-1}=3: 2$. Um semicírculo com seis divisões iguais é a metade de um círculo de 12 divisões, ou seja, a totalidade do círculo de quintas, $(3: 2)^{12}$, os doze termos pelos quais uma nota inicial fundamental - dó, por exemplo - "retornaria", sete oitavas acima $\left(2^{7}\right)$, para si mesma (fig. 5). Porém, um outro círculo, de quartas justas ascendentes (fig. 6), análogo ao anterior e igualmente de 12 termos, poderia ler estas mesmas notas do círculo de quintas descensionais, $(2: 3)^{12}$, como uma ascensão das referidas quartas, $(4: 3)^{12}$, os doze termos pelos quais a mesma nota dó inicial "retornaria" para si mesma, com a diferença de que, neste caso, não mais sete oitavas acima, como quando por quintas, mas sim cinco oitavas acima $\left(2^{5}\right)$, uma vez que, sendo 4:3 $(1,333 \ldots)$ menor que $3: 2(1,5)$, em várias destas oitavas cabem mais do que uma nota (fig. 6). 


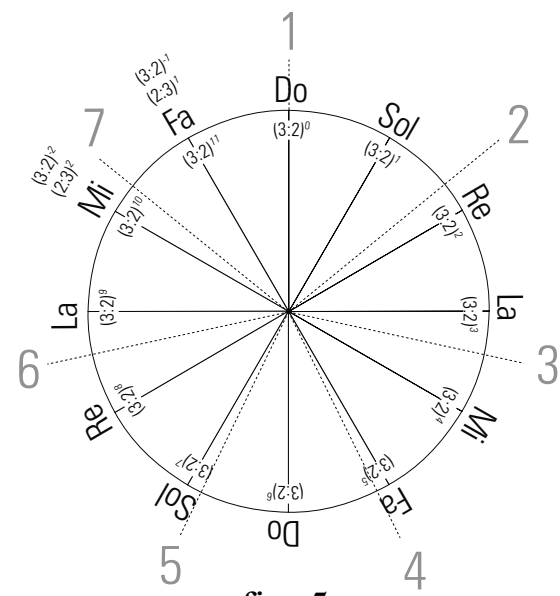

fig. 5

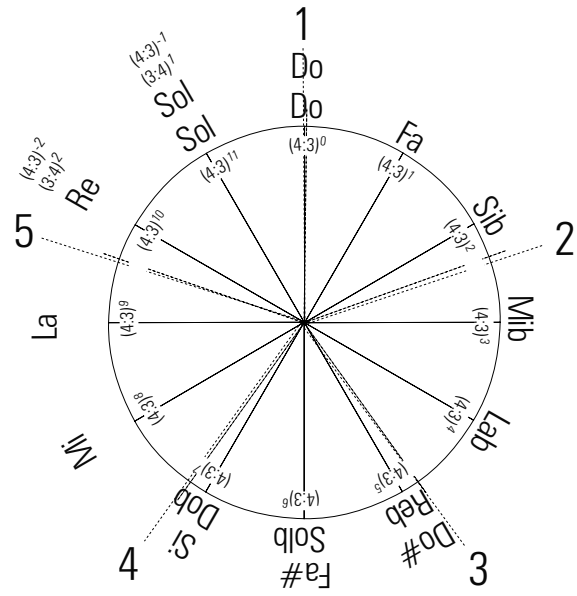

fig. 6

Retomemos, agora, o passo da criação da alma do mundo no Timeu, do exato ponto em que o interrompemos, ou seja, com o texto que subseqüencia as sete divisões nas porções que descrevemos.

\section{As Três Proporções e Suas Mediedades}

Preencheu os intervalos duplos e triplos, destacando porções da mistura primitiva, dispondo-as entre aquelas partes, tal que de cada 
intervalo houvesse duas mediedades. A primeira superando e sendo superada por uma mesma fração dos extremos [a média harmônica]. A segunda superando um extremo por um número igual àquele pelo qual é superada pelo outro [a média aritmética]. Dessas relações nascem os intervalos já designados [as razões duplas e triplas], intervalos novos de um mais um meio [3:2, a média artimética], de um mais um terço [4:3, a média harmônica], um mais um oitavo [o tom inteiro, 9:8] (Timeu 35 c - 36 a).

Voltando ao Timeu, vemos que este último momento citado começa por definir as duas mediedades, a harmônica e a aritmética, em termos praticamente idênticos à definição do Epinomís que citaremos mais adiante. Em perfeita consonância com o preceito platônico da alma enquanto uma totalidade tripla, Proclo afirma que cada parte desta também é tripla, reunindo, ao modo de cada parte, as três naturezas do todo, essência, mesmidade e alteridade. Enfatizemos: cada parte participa da estrutura tríplice da totalidade tripla, estrutura já primordialmente dada na natureza da terceira substância, na qual a essência reúne as outras duas naturezas, a mesmidade e a alteridade. Para Proclo, esta abrangência da essencialidade sobre a mesmidade e a alteridade é traduzida pela abrangência da proporção geométrica sobre a harmônica e a aritmética (Proclus, 1990, p. 78).

A média geométrica, em concordância com a essencialidade advinda da terceira substância, conecta todas as coisas que são essenciais nas almas, "pois a essência é uma única razão percorrendo todas as coisas, e, por conectar as naturezas primeira, intermediária e última, tal como a média geométrica, que é uma e mesma razão, permeia perfeitamente os três termos envolvidos na proporção" (Proclus, 1990, p.78). Já em concordância com a mesmidade advinda da abrangida natureza do Mesmo, na terceira substância, enquanto correspondência da indivisibilidade, a média harmônica conecta a referida mesmidade dividida das almas, concedendo aos extremos uma comunhão de razões. "Certamente, a mesmidade é vista em um grau maior nas naturezas mais totais e em um grau menor nas mais parciais" (Proclus, 1990, p. 78). Porém, o reino ou domínio da mesmidade, e portanto de sua mediedade correspodente, é o das naturezas mais excelentes e totais, ou seja, dos todos advindos da harmonia das partes. Já a média aritmética, em concordância com a alteridade, tem a capacidade de unir as diversidades todo-variadas da alma, sendo, ao contrário da média anterior, mais inerente às coisas que são pequenas, uma vez que a diferença, conceito que pode substituir o de alteridade, tem como preponderante domínio as naturezas mais parciais. 
Boécio e Proclo, entre outros sintetizadores e comentadores, explicitam a propriedade da média geométrica mediar as outras duas mediedades, a aritmética e a harmônica, obviamente além dos extremos (Boetius, De institutione arithmetica, L. I c.1). Proclo diz que Platão no Timeu observa que a média geométrica é aquela que compreende as outras duas, e que é a partir dela que estas últimas se desdobram na forma das razões sesquiáltera (um acrescido de sua metade, 3:2, a média aritmética) e sesquitércia (um acrescido de sua terça parte, 4:3, a média harmônica) (Proclus, 1990, p. 78) ${ }^{12}$.

Já o próprio Platão, no Epinomís, sintetiza o entrelaçamento das três mediedades:

O primeiro exemplo desta razão de dobro é aquela que, avançando pela série dos números, é de 1 para 2; o dobro desta é igualmente a razão de seu quadrado; e novamente o dobro desta a que se dirige para o sólido e o tangível (991 a).

Observemos que é através da progressão geométrica encadeando oitavas que Platão, por uma cadeia de duplos que perpassa todos os estágios prefigurados na tetraktýs $\left(1,2,2^{2}, 2^{3}\right.$ : ponto, linha, plano e sólido), pré-estipula o campo da manifestação, descendo pela razão óctupla (1:8) do cosmos modelar até o fundamento do cosmos visível e tangível. Tal progressão geométrica, que Proclo em consonância com Platão define como a mais bela, é a base apriorística do entretecimento das outras mediedades. Ainda no Epinomís, Platão assim continua:

Finalmente, na escala que vai do dobro ao termo médio, uma das médias é eqüidistante dos extremos, já que excede ao termo menor em uma quantidade igual àquela em que é excedida pelo termo maior; a outra excede o termo menor e é excedida pelo maior pela mesma fração dos termos respectivos; e assim se formam as razões de 3:2 e 4:3 que serão encontradas como médias dentro da gama que vai de 6 a 12. É por esta progressão, com o duplo sentido direcional efetivado por meio destas últimas razões, que recebemos uma dádiva do abençoado coro das Musas, às quais a humanidade deve o benefício do jogo da consonância e da medida, com toda a contribuição ao ritmo e melodia [grifos nossos] (991 a-b).

Platão define a média aritmética como aquela que é eqüidistante do termo menor e maior. Assim, se tomamos o primeiro exemplo de razão dupla na pro- 
gressão geométrica dos números, 1:2, a média aritmética entre estes dois extremos é 3:2, ou seja, 3 projetado uma oitava abaixo, vale dizer, dividido por 2 . $\mathrm{O}$ deslocamento de oitava descendente, expresso pela divisão por 2, pode ser anulado pela operação inversa, a multilicação por 2, a qual nos devolveria à inteireza do número 3 como média aritmética da oitava modelar (1:2) projetada para o segundo par de duplos da mesma progressão geométrica primordial, 2:4.

$\mathrm{Na}$ breve definição da progressão aritmética do parágrafo anterior, dois tipos interligados de operações foram mencionados, a saber, o deslocamento de oitavas pela multiplicação ou pela divisão por 2, operações que têm como objetivo a restrição de várias oitavas ao modelo de uma única (divisão por 2), e a expressão dos tons, dentro do possível, com os números inteiros (multiplicação por 2). É a progressão geométrica dos duplos $\left(2^{\mathrm{n}}\right)$, na qual a dupla oitava está inserida ( $4: 2:: 2: 1)$, que permite, dada a perfeita equivalência das razões nela envolvidas, a restrição de tal dupla oitava, ou de quantas outras mais tivéssemos, a um modelo de oitava única, 2:1, no qual poderemos projetar as outras duas mediedades. Assim, quando uma determinada operação resulta em números fracionários ou decimais, estes são multiplicados, ou projetados em oitavas superiores, quantas vezes forem necessárias, em prol da obtenção de um inteiro pleno de significação. E é exatamente em nome desta plenitude de significado que se realiza a operação inversa, ou seja, sucessivas divisões por 2, ou projeções em oitavas inferiores, para que a restrição aos números inteiros se dê, dentro do possível, aos primeiros dez, a década da aritmosofia pitagórica.

Recordemos que a restrição de duas ou mais oitavas, enquanto sucessão de delimitações de planos entropicamente imitativos da criatividade demiúrgica primordial, a uma única oitava modelar, além de encontrar perfeito fundamento na teoria musical (para a qual todas as oitavas têm o mesmo padrão), encontra em vários momentos da República, tais como 472c ou 500e, sua justificativa ontológica, a qual podemos ver relativamente explicitada em outro passo deste diálogo:

E deus, seja porque não quis, seja porque a necessidade o obrigou a não operar mais que uma cama na natureza [objeto que, em empatia com o próprio corpo humano, pode ser a insinuação do denominado quadrado duplo ou retângulo de $2: 1$, ou seja, da oitava musical ou diapasôn], fez esta cama única de que falamos, a cama mesma ou essencial. Podes ter por certo que deus não produz nunca duas ou mais camas (República 597 c). 
Tal restrição a uma oitava modelar é mais uma das chaves essenciais para a decodificação da teoria da harmonia em Platão, pois ele é herdeiro do preceito pitagórico que restringe a generalidade numérica aos números inteiros. Platão justifica, em três passos da República, estes procedimentos da seguinte maneira: "a estes filhos teus [...] eu não suponho que, enquanto se portam como linhas irracionais, lhes permitiria governar na cidade" (República 534 d); e quando os verdadeiros filósofos chegarem ao poder, "serão mandados para o campo todos aqueles que na cidade tenham ultrapassado dez anos de idade" (República 541 a); e, finalmente, "sabes certamente que aqueles que têm destreza nestas coisas [...] ridicularizam e não dão ouvidos àquele que trata de dividir a unidade em si. E se tu a divides, eles mesmos multiplicam, temerosos de que a unidade, parecendo uma reunião de porções, não mais se assemelhe ao que é" (República 525 e). Concluindo, acrescentaremos apenas que a plena significação dos primeiros dez inteiros, para além da tradução de cada um deles como presentificadores de leis fundamentais que regem o universo, também deve ser entendida, na ótica da ciência da harmonia, pela plenitude tensional de suas relações, razões e proporções.

Quanto à progressão harmônica, se partimos da unidade obtemos o seguinte encadeamento de frações: $1,1 / 2,1 / 3,1 / 4$, etc. Se então quisermos transformar os quatro primeiros termos desta série nos menores números inteiros possíveis, devemos partir de 12, de modo a obter os seguintes números: 12, 6, 4, 3, exatamente os números do início da discussão entre Sócrates e o tirano Trasímaco no livro I da República, dos quais os dois primeiros, 6 e 12, são também mencionados como o par de extremos, uma oitava, no passo sobrecitado do Epinomis.

Ora, neste mesmo passo, Epinomís 991, Platão define a média harmônica como aquela que excede o primeiro termo pela mesma fração que é excedida pelo outro termo. Na série $1,1 / 2,1 / 3,1 / 4$, etc., qualquer termo é a média harmônica dos circunvizinhos. Assim como $1 / 3$, a média harmônica entre $1 / 4$ e $1 / 2$, supera o primeiro extremo, $1 / 4$, em $1 / 3$ deste, assim também $1 / 3$ é superado pelo segundo extremo, $1 / 2$, em $1 / 3$ deste. Se tomamos como extremos os que compõem o primeiro exemplo de razão dupla, 1:2, então, a média harmônica, 4:3, é aquela que, acrescentando $1 / 3$ ao primeiro termo - e compondo a nova medida de um e um terço -, será $2 / 3$ do segundo termo, $2 / 3$ que se diferencia de 2 , o segundo termo, pela mesma fração que foi acrescida a 1 , ou seja, $1 / 3$.

Para que a média harmônica atinja a expressão do menor número inteiro possível, necessitamos, como indica o próprio denominador de 4/3, multiplicar 
os três termos nela envolvidos - 1, 4:3 e 2 - por 3 , o que resulta respectivamente em 3, 4 e 6 . Assim, 4 é 3 acrescido da terça parte deste, e é $4 / 6$ ou $2 / 3$ de 6 , o que equivale a dizer que 6 o ultrapassa em uma terça parte de 6 , ou seja em $6 / 3$ ou 2 , que por sua vez é, obviamente, $1 / 3$ de 6 , a mesma fração proporcional pela qual 4 ultrapassa 3.

A notação algébrica moderna para a média harmônica é, tendo a e $b$ como extremos, $2 a b / a+b$, notação que MacClain diz mais velar que desvelar. Um pouco melhor é a fórmula, antecedente a esta, que define a média harmônica como sendo o inverso da média aritmética dos inversos dos termos extremos, o que leva MacClain a defini-la como o subcontrário da média aritimética (MacClain, 1984, p. 12). Assim, inverteríamos os termos extremos, transformando-os em $1 / a$ e $1 / b$, descobriríamos a média aritmética pelo termo eqüidistante destes extremos invertidos, e, na posse deste resultado, efetivaríamos sua inversão. Com esta última formulação, pelo menos o duplo espelho que havíamos apontado como característica fundamental da reciprocidade (ver nota 11) ganha um nível de desvelamento e explicita sua presença entre as duas mediedades, a aritmética e a harmônica.

É pela dinâmica gnomônica da progressão triangular que podemos visualizar o despontar das mediedades aritmética e harmônica entre os termos extremos de uma oitava (cf. fig. 7).
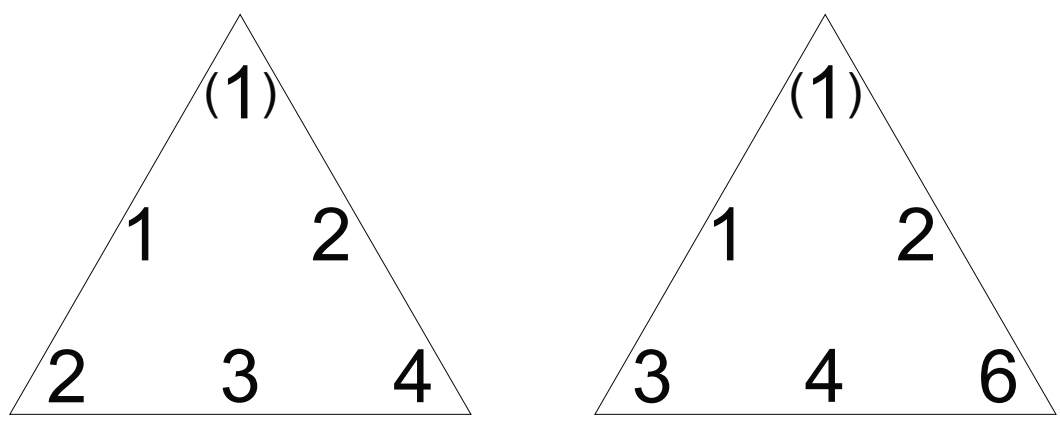

fig. 7

As duas expansões triangulares acima, tal como temos demonstrado, auto-evidenciam a reciprocidade das duas mediedades, uma sendo o espelho da outra. Pois com os termos 2, 3 e 4 (3 como a média aritmética dos extremos 2 e 4) temos uma relação de razões onde $3: 2>4: 3$, enquanto que com os termos 3, 4 e 6 (4 como média harmônica dos extremos 3 e 6) temos exatamente o 
espelhamento da mesma relação de razões, onde 4:3<6:4, sendo que 6:4 é 3:2. É forçosa, portanto, a conclusão de que ambas as mediedades são, de certa forma, duas facetas da mesma intermediação fundamental colocada em uma reciprocidade especular. "Estas duas médias têm algo pelo qual se comunicam uma com a outra, tal como a mesmidade com a diferença", afirmação de Proclo (Proclus, 1990, p. 78-9) que pode ser remetida à reciprocidade implicita entre elas, reciprocidade que as irmana como gêmeas sob a mesma "paternidade" do número primo 3 .

E como a essência é também a mônada para as anteriores [a mesmidade e alteridade], assim a média geométrica é a mônada para as outras duas [a aritmética e a harmônica]. Por causa disso, a média aritmética e a harmônica constituem a consumação da geométrica, da mesma maneira que a mesmidade e a diferença contribuem para a perfeição da essência. É porque a média aritmética e a harmônica subsistem como opostos entre si [na referida reciprocidade especular] que a média geométrica as conecta, e, de certo modo, entrelaça tal oposição (id. ib.).

Mais adiante, no mesmo texto, Proclo afirma, diga-se de passagem, que "essência, mesmidade e diferença estão em cada parte da alma" (id. ib.), tripartição hierárquica que fundamenta a reunião em cada uma das partes e no todo que as integra.

Porém, as duas progressões triangulares - que, repetindo, são, de certa forma, a mesma- carecem de um fechamento tetrádico que englobe e dê a injunção de uma igualdade superior à desigualdade das referidas razões; e se, para expressar as mediedades em questão através dos menores números inteiros possíveis, transpomos a oitava primordial multiplicando seus termos (1 e 2) por 2, para a obtenção da média aritmética, e por 3, para a da média harmônica, então, o referido fechamento tetrádico, que simultaneamente expressará ambas com os menores inteiros possíveis, exige que os termos da oitava principial sejam multiplicados por 6, ou seja, por 2 e por 3 ao mesmo tempo. 


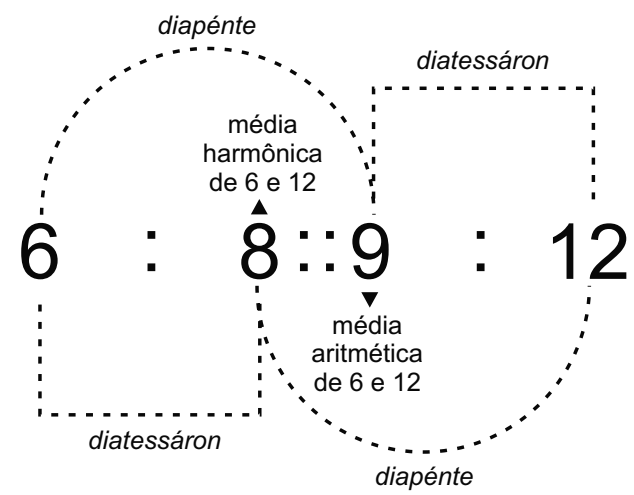

fig. 8

$\mathrm{Na}$ fig. 8, a resultante seqüência de quatro termos $-6,8,9$ e 12 -, como vemos acima, congrega, por quatro passos triangulares descensionais na direção de um fechamento nesta tetraktýs, as duas mediedades expressas como números inteiros. A desigualdade inerente a cada uma delas $(6: 9<9: 12$ e $6: 8>8: 12)$ integra enquanto subsidia o entrelaçamento de uma igualdade superior (6:8::9:12, pois $6: 8=9: 12$, e $6: 9=8: 12$ ).

Sempre consonante com a perspectiva teológica de sua exegese, Proclo, além da dimensão cosmogônica que tem nas três mediedades os fundamentos do tecer demiúrgico, efetiva uma leitura teogônica, conectando-as com as três filhas de Thémis. A média geométrica é uma imagem de Eunomía, a lei tolerante, que Platão, nas Leis, celebra como aquela que adorna o universo e compreende a verdadeira ciência política; a harmônica, de Díke, a justiça, distribuindo uma razão maior para os termos maiores, e uma menor para os menores; a aritmética, de Eiréne, a paz, pois concede a todas as coisas a igualdade segundo a quantidade; e a reunião das três mediedades em uma única progressão concordante é consagrada à mãe destas três filhas, Thémis, para a qual Proclo usa a expressão "analogia sólida" (Proclus, 1990, p. 77-8).35

\section{A Escala Pitagórica}

Pelo intervalo de um e um oitavo [o tom inteiro], Deus completou todos os intervalos de um e um terço [4:3, diatessáron que assim preenchida comporá um tetracorde que terá dois 
tons inteiros e um "semitom" pitagórico, conjunto de quatro notas escalísticamente seqüenciadas], deixando como resíduo uma porção de cada um deles de modo que o intervalo residual fosse definido pela razão dos números 256 e 243 [razão do "semitom" pitagórico, denominado leîmma]. E assim, a mistura na qual fizera essas divisões, pode empregá-la totalmente (Timeu $36 \mathrm{a}-\mathrm{b}$ ).

Proclo vê que Platão estabelece uma graduação descendente de principialidades, rumo à manifestação concreta, pela qual a média geométrica antecede a harmônica e a aritmética, e estas duas antecedem as razões de um e um oitavo (9:8, o tom inteiro) e os leîmmata ou os restos subsistentes (a menor medida intervalar no campo da afinação pitagórica que é a razão de 256:243, o semitom) (Proclus, 1990, p.78).

Com o descenso até as razões de 9:8 (o tom inteiro) que, juntamente com o resto subsistente do leîmma, preenchem todos os intervalos de 4:3 (os tetracordes), Platão atinge a plenitude do setenário, base da escala diatônica na música e estrutura subjacente a todos os modos.

O semicírculo de sete razões em progressão geométrica que extraímos da lámbda platônica levou-nos a escolher, na fig. 4, a nota récomo fundamental (1) de forma a obter um conjunto de notas delimitado às teclas brancas do piano, a forma mais simples de apontar, para não-músicos, a estrutura diatônica. Importa-nos agora que, da mesma forma que os sete modos (que correspondem a essas sete notas) se mantêm dentro do conjunto das mesmas sete (apenas distribuídas, por exemplo, de dó a dó, de ré a ré, etc.), este semicírculo de quintas também pode como que girar dentro do círculo total ao qual pertence, fazendo com que a fundamental 1 possa ser atribuída a qualquer outra dentre as sete. Esta operação é importante para que a fundamental 1 recaia sobre a nota dó, e, dessa forma, possamos usufruir do fato desta nossa tão conhecida escala, a escala ascensional de dó a dó, ter a mesma estrutura intervalar, a despeito de invertida, do principal modo grego, o dórico (de $m i$ a $m i$ ), base da concepção escalística do Ocidente tradicional. Por mais que esta transposição, que levará o número 1 a incidir sobre dó mas manterá o mesmo conjunto de notas, produza novas razões, estas sempre permanecerão dentro da estrutura da mesma progressão geométrica, vale dizer, $(3: 2)^{\mathrm{n}}$, como se vê da fig. 9 . 


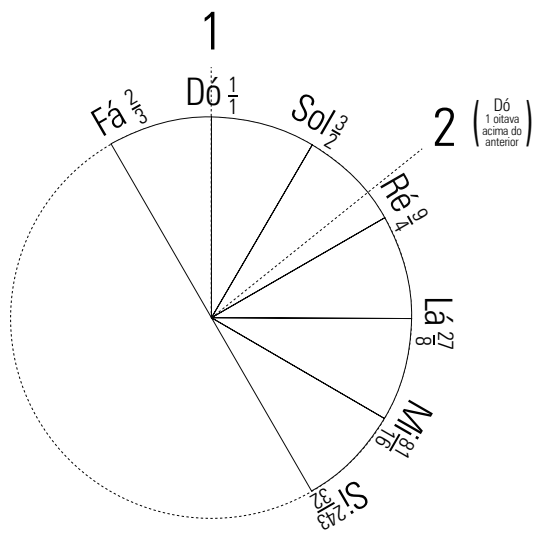

fig. 9

As duas linhas pontilhadas representam a oitava, 1 e seu dobro, na razão dupla de 2:1, na qual já se faz presente a média aritmética 3:2. Servindo-nos da operação que, multiplicando e dividindo por 2, efetue transposições de oitavas com todos os termos que estão fora desta oitava entre 1 e 2 , podemos trazê-los para dentro desta ${ }^{13}$. O conjunto destas reduções das razões para o âmbito de uma oitava resultará nas escalas da fig. 10.

a)

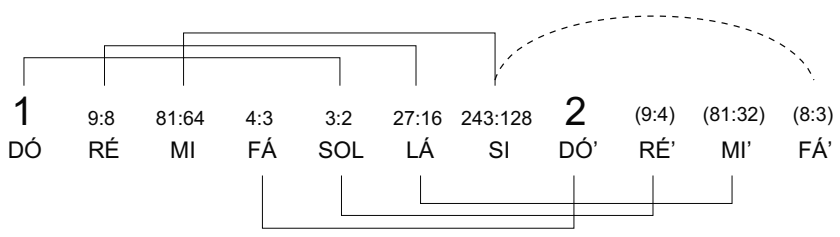

b)

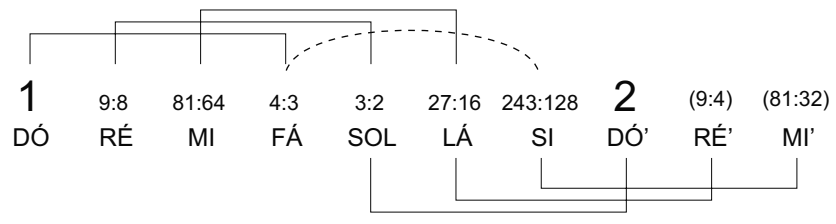

c)

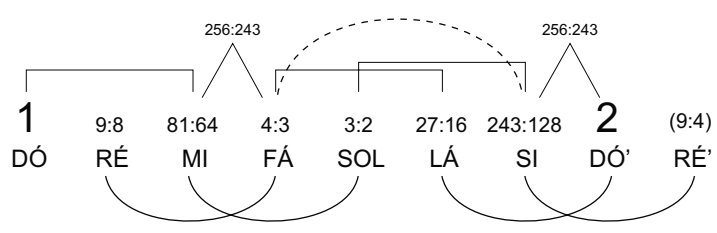

fig. 10 
Esta escala tem a afinação denominada pitagórica, afinação cuja característica fundamental é que sua elaboração, por estar baseada no círculo de quintas, é a adequação possível, dentro de uma irredutível inadequação dada, das potências de 3 (as quintas) e das potências de 2 (as oitavas), uma vez que um número restrito de quintas encadeadas é reduzido por projeções oitavadas à oitava, vale dizer, à razão dupla de 2:1. Tais potências de 2 e de 3 já são incomensuráveis entre si, mas sua adequação possível, o temperamento pitagórico, configura a primeira e, neste âmbito principial, única alternativa ao caos. Evidentemente, acrescentamos notas entre parêntesis para que pudéssemos realizar algumas medições intervalares que extrapolam o âmbito restrito da escala mas que são relações inerentes a ela.

Em a, evidenciamos que todas as quintas ou diapénte são perfeitas (um resultado óbvio uma vez que o encadeamento de quintas, 3:2, em progressão geométrica foi nosso ponto de partida), todas menos uma, envolvendo as notas si e fá, uma quinta diminuta, a qual destacamos com a linha pontilhada. Em $b$, demonstramos a uniformidade das quartas perfeitas ou diatessáron - outra obviedade musical uma vez que uma quarta justa é uma inversão de uma quinta - mas, novamente, todas menos uma: fá e si, uma quarta aumentada que também destacamos com a linha pontilhada. Em $c$, a partir da distância de dois tons inteiros, $(9: 8)^{2}=81: 64$, apontamos com chaves retangulares os lugares deste intervalo denominado terça maior; com linhas curvas apontamos a presença de um intervalo subjacente que ainda não havia sido mencionado, a terça menor (contendo três semitons, ou seja, um tom e meio) de razão 32:27; apontamos os dois lugares da relação subsistente de 256:243, o leîmma ou "semitom" da afinação pitagórica, a menor distância intervalar possível dentro desta afinação, envolvendo as duas notas "tensas", fá e si, o trítono ou três tons inteiros, $(9: 8)^{3}$, que resulta em 729:512 (243:128, si, dividido por 4:3, fâ), que, por este motivo, novamente destacamos com a linha curva pontilhada, intervalo que, agora, adentraremos.

O número 729 pertence à progressão geométrica dos triplos. Como em termos musicais 3 é o número inteiro que expressa a quinta justa (3:2), então 729 pode ser intervalarmente medido, na forma de uma nota musical, como uma das quintas que sucedem uma fundamental dada, $3^{\circ}$ ou 1 . Se tomamos tal fundamental como dó, e, portanto, o consideramos como o primeiro termo da progressão, devemos então contar sete termos, pois 729 é $3^{6}$, e atingiremos fáł. Como esta nota dista em muitas oitavas da nota fundamental, para que uma medição ocorra dentro do modelo de uma única oitava, devemos ascender esta última 
quantas oitavas forem necessárias, multiplicando seu número sucessivamente por 2, seguindo o encadeamento dos duplos. Contando a fundamental como primeiro termo, no décimo, $2^{9}$, atingimos a proximidade almejada, pois 512 é o dó imediatamente inferior a este fáł, e a medida da relação intervalar entre eles é, como dissemos acima, três tons, o trítono $(9: 8)^{3}$, o que faz de 729 o número inteiro que expressa tal intervalo. Nove, o quadrado de 3, é o inteiro que expressa o tom, e seu cubo, o trítono. Se dividimos 729 por 512, obtemos 1,42, expressão decimal advinda da expressão fracionária mais próxima, dentro do possível, da raiz quadrada de $2 x 1$, ou seja, da raiz quadrada da multiplicação dos extremos (a própria fórmula para a obtenção de uma média geométrica), de forma que o trítono é a média geométrica dentro da oitava. Portanto, dentro do "espaço" musical da oitava justa, o trítono é uma forma especial de "metade" desta oitava, a metade de uma curva exponencial específica. Enfatizemos: a raiz quadrada de 2 é a "metade" de uma oitava, ou seja, é $2^{1 / 2}$, a metade da potência entre $2^{0}$ ou 1 , a fundamental, e $2^{1}$, a oitava imediatamente superior, e não 3:2 $(1,5)$ como linearmente se esperaria entre 1 e 2 .

Tal "metade" é o ponto mais distante que pode haver da fundamental, pois distancia-se igualmente desta e de sua projeção oitava acima. Ela cria uma nova e especial forma de alteridade, o reduto máximo da incomensurabilidade, tal como a diagonal que divide ao meio o quadrado de 1 por 1 (1:1 que expressa exatamente uma fundamental) é o despontar, no seio da unidade referenciadora, da raiz quadrada de 2, geometricamente auto-evidente porém aritmeticamente incomensurável. E da mesma forma que com a diagonal do quadrado de 1:1 pouco resta a fazer senão uma expansão gnomônica que parta dela enquanto novo lado de um novo quadrado, também o trítono dentro da oitava, por ser o ponto mais distante da fundamental, é a outra fundamental, uma anti-fundamental.

Tudo isso Platão expressa em alegorias. No Fedro, por exemplo, Platão discorre sobre nove tipologias humanas, sendo o filósofo a primeira e o tirano a última (248 c-e). Nos termos de sua herança pitagórica, tal como estamos vendo no Timeu, 9 deve ser pensado como o quadrado de 3. Pensar as nove tipologias a partir desta forma (o quadrado de $3 \times 3$ ), significa pensá-las dentro de uma ordenação determinada por dois parâmetros triplos, um vertical e outro horizontal: o primeiro descendendo por três níveis cognitivos - nóesis, diánoia e pístis -, enquanto o segundo, encaminhado da esquerda para a direita a partir da intersecção perpendicular do eixo vertical, gradua as três partes dominantes da alma - a racional, a impetuosa e a apetitiva ${ }^{14}$. Nesta ordenação das nove tipologias huma- 
nas, o filósofo será a "co-incidência" do plano intelectivo macrocósmico com a parte da alma mais elevada, isto é, a razão, de modo que 1:1 seja a medida da plenitude de sua felicidade; já o tirano estará restrito à intersecção do mundo da persuasão com a parte apetitiva da alma, de modo que 1:9 seja a medida de sua felicidade, nove vezes menos feliz que o filósofo.

No livro IX da República, a vida aprazível é, segundo Brumbaugh, abordada em três dimensões: a correção na escolha dos fins (phrónesis), a habilidade na seleção dos meios para os fins escolhidos (sophrosýne), e as oportunidades para pôr em operação os meios selecionados em prol dos fins escolhidos (andreía) (Brumbaugh, 1989, p. 84; República 433 c). É esta tridimensionalidade que erguerá, a partir da base plana de um quadrado (o do Fedro), um cubo. Novamente, o número da felicidade do tirano, visto agora no livro IX da República, está na razão de 1:9 em relação ao aristocrata, mas isso em cada uma das três dimensões. Como a desmesura tirânica desconsidera todas as três dimensões ou virtudes, para a obtenção de tal medida em relação ao filósofo, 9 (expressão inteira de 1:9) deve ser projetado em três escalas eneárias, ou seja, deve ser multiplicado por ele mesmo duas vezes, resultando em $729,(9)^{3}$, a dissonância máxima (o trítono) da verdadeira vida aprazível, número que mede o quanto o tirano é menos feliz que o rei de si mesmo, o filósofo.

A escala musical concebida no Timeu é um arrazoado provável sobre a escala da criação demiúrgica em seu encaminhamento do cosmos modelar em direção ao cosmos visível. Então, todos os seus componentes são explicados como derivações gradativas de um conjunto limitado de tons unidos aritmeticamente pelas potências de 3 , o procedimento fundamental da denominada afinação pitagórica, e, portanto, musicalmente por quintas e quartas justas. Na República esta afinação corresponde ao modelo descrito por Sócrates como o melhor, mas que, em obediência isomórfica à compulsória reentrada na caverna, deve ser inexoravelmente acompanhado pelo pior (República 363-73), a afinação que passou para a história como a sintônico-diatônica de Ptolomeu, denominada de justa, não mais baseada estritamente, como a anterior, nos princípios concordantes do quaternário ou da tetraktýs principial, mas no senário (1:2:3:4:5:6).

O primeiro modelo, o melhor, correspondente à afinação pitagórica, não é, como já apontamos, de todo desprovido de crise, pois as potências de 3, articuladoras do encadeamento de quintas (3:2) e quartas (4:3), já são, no menor índice crítico, incomensuráveis com as potências de 2 , articuladoras da consecução das oitavas. No segundo, o pior, correspodente à afinação sintônico-diatônica assentada no senário, a crise é amplificada, pois, por sobre a incomensurabilidade 
já dada das potências de 3 e de 2, temos agora, pela extrapolação do âmbito do quaternário para o do senário, a inserção das potências de 5 (um novo número primo), incomensuráveis com ambas anteriores, o que significa que as novas razões superparticulares advindas de tal extrapolação, 5:4 (a terça maior) e 6:5 (a terça menor), são incomensuráveis com as quintas (3:2) e com as quartas (4:3), e, obviamente, com as oitavas.

$\mathrm{Na}$ fig. 7, vimos que o som fundamental retorna para si sete oitavas acima após doze termos do círculo de quintas, ou seja, da progressão geométrica cuja constante é 3:2. Se isto fosse inteiramente verdadeiro, e não apenas uma importante porém irredutível aproximação, então, neste exato ponto de resgate do som fundamental, uma potência de 3 coincidiria com uma de 2, por fazer com que $(3: 2)^{12}=(2: 1)^{7}$, o que, por ser impossível, não pode ser verdade no sentido de uma rigorosa exatidão. Na realidade da precisão logística, $(3: 2)^{12}$ ultrapassa $(2: 1)^{7}$, e a diferença que mede tal ultrapassagem é obtida, tal como todas as diferenças intervalares, pela divisão dos dois termos em questão, $(3: 2)^{12} /(2: 1)^{7}$, resultando em uma famosa razão, decisiva na ciência da harmonia, 531441:524288, conhecida historicamente como a coma pitagórica, uma falha inerente à própria estruturação mais ideal da afinação efetivada pela pureza das potências de 3. Alegoricamente, Platão expressa isso como a falha intrínseca presente na harmonia da casta mais nobre, a dos governantes, pela falta de um rígido princípio de autolimitação determinada pela inobservância dos ciclos de fertilidade (correspondente ao encadeamneto de quintas pelas potências de 3) e de esterilidade (correspondente às proliferantes porém eróticamente estéreis oitavas geradas por cissiparidade, ou seja, pelas potências de 2), falta esta que acaba por gerar exatamente os "filhos não-musicais" referidos por Sócrates na República 546.

É interessante observar que a razão da coma pitagórica, que poderia ser formulada como $3^{12}: 2^{19}$, obtida através da instância macroescalar de 12 quintas comparadas a 7 oitavas, se mantém intacta em instâncias microescalares. Assim, dentro de uma única oitava, seis tons inteiros ultrapassam-na pela mesma razão, pois $(9: 8)^{6} / 2: 1=531441: 524288$. Também dentro de um único tom, quando dele extraímos dois semitons pitagóricos (ou seja, dois leîmmata de 256:243), a diferença irredutível dá-se pela mesma razão da coma pitagórica, pois 9:8/(256:243) ${ }^{2}$ = 531441:524288. A propósito desta última instância, ou seja, a da coma pitagórica enquanto expressão da diferença do tom inteiro (9:8) e de duas leîmmata $(256: 243)^{2}$-, observemos que, pitagoricamente, tal coma é a diferença entre dois semitons diatônicos, um ascendente e outro descendente, colocados entre um tom. Assim, entre fá (4:3) e sol (3:2), as duas mediedades dentro da oitava de dó 
a dó pelas quais desponta o tom inteiro de 9:8, solb, o semitom ascendente que parte de fá, é 4:3 X 256:243=1024:729, e fáf, o semitom descendente que parte de sol, é 3:2/256:243 = 729:512. A diferença entre estes dois resultados, 729:512/ 1024:729, que, obviamente, é a diferença entre solb e fał, é exatamente a coma pitagórica, 531441:524288.

Resta-nos ainda observar que não foi nem um pouco arbitrária a escolha de solb e fa\# como exemplos de semitons entre os quais subsiste a diferença irredutível da coma pitagórica. Muito pelo contrário, tais semitons expressam o ponto diametralmente oposto, no círculo de quintas, ao da fundamental dó (1), ponto no qual a carência de auto-limitação na geração de "filhos" advindos das potências de 3 , enquanto quintas à direita (rumo aos sustenidos) e à esquerda (rumo aos bemois), caracteriza o conflito real e nominal de duas notas musicais que, não sendo idênticas (embora, de certa forma, esperaríamos que fossem), caracterizam a diferença irredutível, não-afinável, designada pela razão da coma pitagórica, proveniente da inobservância dos ciclos de esterilidade (as potências de 2) e de fertilidade (as potências de 3), e assim o fazem exatamente como duas versões do já comentado trítono cujo número, 729, é o mesmo, tal como já apontamos, do tirano (cf. fig. 11).

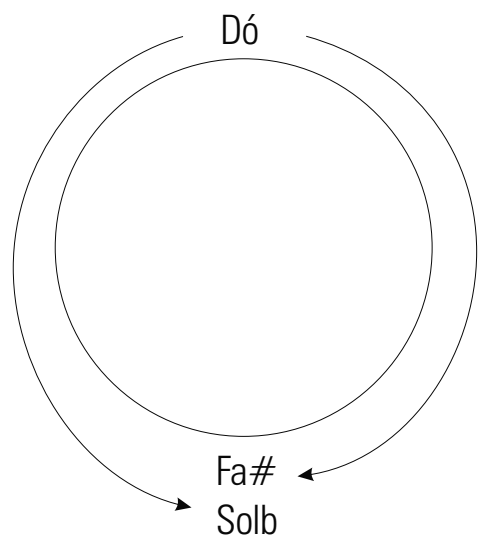

fig. 11

\section{A Escala sintônico-diatônica}

Adentremos agora os apontamentos sobre a incomensurabilidade no modelo designado por Sócrates como o pior, ou seja, no modelo representado 
pela escala sintônico-diatônica, que tem como fundamento a afinação assentada no senário, a qual exemplificamos na fig. 12 .

a)

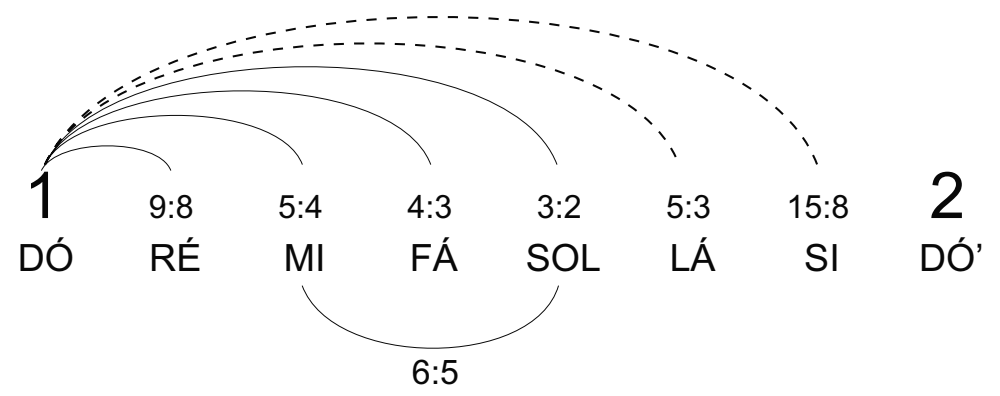

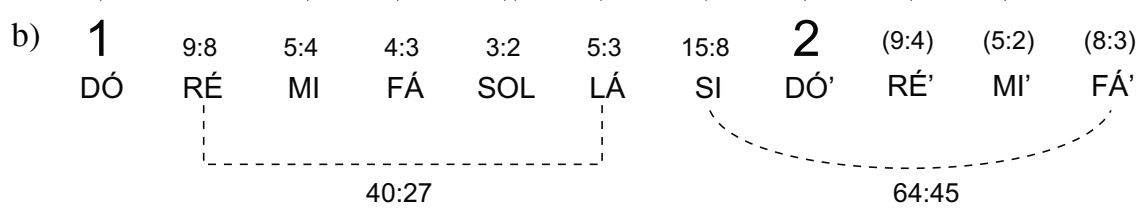

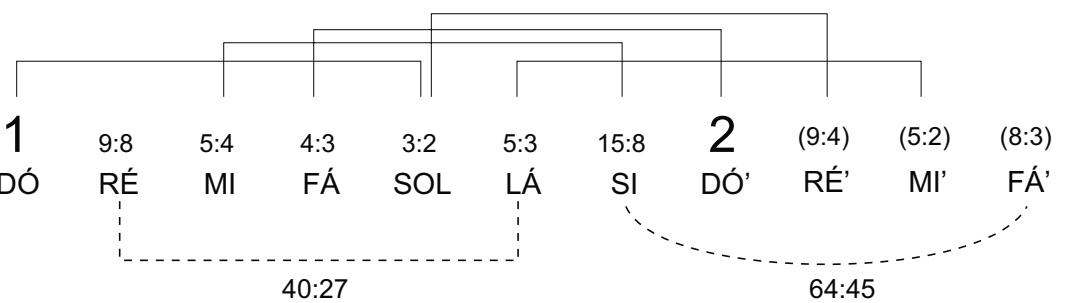

c)

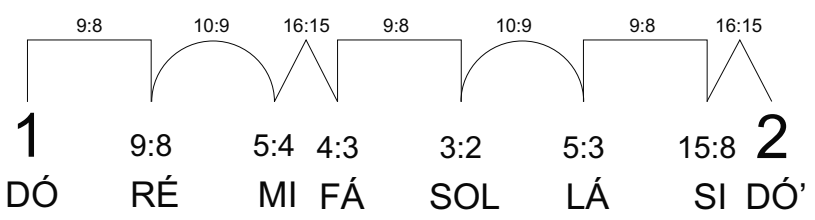

fig. 12

Em a, apontamos com linhas curvas cheias a presença das razões superparticulares com os termos do senário dentro da razão dupla, a oitava (2:1), e destacamos a presença da terça menor (6:5) entre as notas $m i$ e sol, exatamente aquelas que, na série harmônica, correspondem aos números envolvidos nesta razão. Também destacamos com linhas curvas pontilhadas a presença de duas razões superpartientes que caracterizam as medidas, frente à fundamental dó (1), dos intervalos de um e dois terços - a sexta maior (5:3), com a sexta nota da escala, lá e de um e sete oitavos - a sétima maior (15:8), com a sétima nota da escala, $s 1^{15}$. 
Em $b$, além das quintas justas perfeitas, com traço cheio, apontamos, com linha pontilhada, a que não o é perfeitamente, mas apenas se aproxima de 3:2 (ré e lá, 40:27); em $c$, dispomos a seqüência escalística composta de dois tipos alternados de tons inteiros - 9:8, um tom inteiro "maior", e 10:9, um tom inteiro "menor" - e os dois semitons, um em cada tetracorde, ambos com razão de 16:15. Afora o semitom - a razão superparticular de 16:15 - e os intervalos das razões superpartientes, os novos intervalos são 5:4, 6:5, 9:8 e 10:9, decisivos para a composição escalística.

Todos estes intervalos podem ser explicados, e assim o foram tradicionalmente, à luz das médias aritmética e harmônica. Sabemos que 3 é a média aritmética entre 2 e 4 , dó'e dó". A projeção destes três termos, multiplicando-os por 2, uma oitava acima dar-nos-ia, obviamente, 6 mediando 4 e 8 . Ora, tomando como extremos 4 (dó’) e $6(s o l)$ - a diapénte 6:4, que é igual a 3:2 - a média aritmética é $5(\mathrm{ml})$, o que explica, voltando à oitava primordial - ou seja, dividindo por 4 - a terça maior 5:4 como a média aritmética entre 1 e 3:2 (3:2 que é a média aritmética entre 1 e 2).

MacClain vê nesta nova média aritmética dentro da quinta justa de razão 3:2 uma das chaves de decifração de um dos passos mais enigmáticos da República, o 546 a-d, que descreve a dissolução da composição, mesmo a mais excelente, que, por ingressar no tempo, neste terá não mais que um tempo de duração. $\mathrm{O}$ núcleo de tal chave estaria, então, em uma frase de tal passo: "Destes elementos, a raiz epítrita [que MacClain (1984, p. 18) traduz como raiz quatro-três, mas que literalmente quer dizer sesquetércia, ou seja, um e um terço ou 4:3] unida com o cinco, aumentada três vezes, produz duas harmonias" [546 c]. Trata-se da razão 4:3, a diatessáron gerada pela média harmônica, dentro da resolução superior dada pela proporção musical 6:8::9:12, ou seja: dó (1) está para fá (4:3) assim como sol (3:2) está para dó (2), duas quartas justas (4:3), de um lado e do outro da proporção. Então, como o 5 pode ser unido à proporção musical? A resposta, segundo MacClain, tem seu fundamento exatamente na média aritmética dentro da quinta justa, a maneira pela qual o "humano masculino", o número primo 5, ingressa na teoria harmônica, resposta esta que é anunciada por Sócrates algumas poucas páginas antes, em 539d-e. Ao declarar, neste passo, que os guardiões devem preparar-se para seus deveres cívicos dispendendo não menos que "o dobro de números de anos devotados à ginástica" ao rigoroso estudo da dialética, ele é indagado: "Quantos anos queres dizer, 6 ou 4?", ao que responde: "Não te preocupes com isso. Admite que sejam 5" (MacClain, 1984, p. 23). 
Já a média aritmética dentro da terça maior - portanto entre 1 e $5: 4$ - é exatamente o tom inteiro maior 9:8, e se quiséssemos expressar estes três termos somente com números inteiros, bastaria multiplicá-los por 8 , projetando-os três oitavas acima, o que resultaria em 9 como média aritmética entre 8 e 10. Temos então uma seqüência de três médias aritméticas: dentro da oitava (2:1), a quinta justa (3:2), dentro desta, a terça maior $(5: 4)$, e dentro desta última, o tom inteiro maior de 9:8. Com esses mesmos três índices de extremos - a oitava, a quinta e a terça maior -, devemos, agora, extrair as médias harmônicas. Da oitava $(2: 1)$ já sabemos ser a quarta justa 4:3, da quinta justa é $6: 5$, a terça menor, e dentro da terça maior (5:4), o tom inteiro menor de 10:9. Eis como as duas mediedades fundamentam, afora o semitom, todos os intervalos musicalmente decisivos para a construção da escala sintônico-diatônica.

Nesta escala sintônico-diatônica, preponderante na República, vigente na natureza do som, chamou a atenção dos pitagóricos que a terça maior 5:4 (mi, em nosso exemplo) não dista 9:8 de 9:8 (ré) de 1 (dó), ou seja, não é 81:64 ou (9:8) (como é o caso da terça maior, 81:64, na escala pitagórica que, no Timeu, representa a escala ideal da ação criacional demiúrgica e, ao restringir-se aos duplos e tríplos, evita, portanto, o número primo 5 enquanto princípio gerador). A terça maior da escala sintônico-diatônica, $m i$ (5:4), dista de ré (9:8) o resultado da divisão de 5:4 por 9:8, ou seja, 10:9, um outro tom "aceitável" e não de todo "destemperado", um tom inteiro "menor".

A existência de dois tipos de tons inteiros, 9:8 e 10:9, dos quais o primeiro é o mais privilegiado, matematicamente incitava a medição da diferença subjacente entre eles. Antes de mais nada novamente lembremos que, para medidas intervalares, uma diferença entre duas razões é obtida pela divisão de uma por outra. A diferença entre estes dois tons, (9:8)/10:9), é 81:80, a coma sintônicodiatônica ou ptolemaica, vulgarmente entendida como a nona parte de um tom, mas, na verdade, aproximadamente a raiz nônupla deste. Como menor parte significante, a coma, enquanto diferença entre duas razões, retrata a mínima diferença irredutível, uma quase identidade ${ }^{16}$, uma quase perfeição ou uma irremediável imperfeição que, ao mesmo tempo, possibilita um campo de temperamento ou ajuste, vale dizer, de aperfeiçoamento. Recordemos que 81, tomando dó como $3^{\circ}$ ou 1 , é o número inteiro que, na afinação pitagórica, é aritmeticamente uma potência de $3,3^{4}$, ou seja, a terça maior mi, enquanto que 80 , projetado quatro oitavas abaixo (e portanto dividido por $2^{4}$ ou 16), resulta no número primo 5 , número que expressa, dentro do senário, a terça maior mi na afinação 
justa da escala ptolomaica ou sintônico-diatônica, o que faz com que a coma sintônico-diatônica retrate, pela mesma nota nominal (o mi, terça maior da fundamental dó), a incomensurabilidade entre as potências de 3 e as de 5 .

No Timeu $50 \mathrm{~d}$, Platão faz-se numerológica e harmonicamente claro ao comparar o recipiente a uma mãe, o emissor, cuja emissão será recebida pelo recipiente, a um pai, e a natureza no meio de ambos, ao filho. Assim, o pai ou emissor corresponde ao ponto referencial imutável, o 1; a mãe ou recipiente, ao 2; o filho, a média aritmética (3:2) entre pai e mãe, ao número primo 3, na transposição oitava acima $(2: 3: 4)$ que temos usado para evitar frações. Mas este filho é sempre acompanhado de sua contraface complementar, de um irmão gêmeo derivado da reciprocidade da média harmônica (4:3), que também envolve 3 , fazendo com que pais e filhos sejam encontrados na proporção musical 6:8::9:12 - proporção na qual cada par de termos comporta uma quarta justa, e na qual devemos inserir o número primo 5 . E se as potências de 2 (as oitavas pares) e as de 3 (as quintas e quartas ímpares) já se mostram inconciliáveis - e cuja coordenação, como dissemos, configura uma alternativa ao caos -, a inserção do número primo 5 (as terças maiores e menores) - agora pela média aritmética e harmônica dentro da quinta justa, tal como uma casta subordinada à dos governantes - aprofunda a incomensurabilidade, frente à qual uma militância cósmica em busca de temperanças e temperamentos sempre deve tentar remediar.

\section{Formação Harmônica do Modelo Astronômico Geocêntrico}

Pelas citações intermitentes que, até aqui, fizemos do passo da criação da alma do mundo no Timeu, Platão, através da dinâmica hierárquico-descensional das mediedades, levou-nos à fundamentação setenária do cosmos. É a partir desta plenitude setenária da escala diatônica que devemos, segundo uma nota de Godwin, entender a enigmática continuidade do passo do Timeu que estamos seguindo. Eis o passo do Timeu:

Ora, toda esta composição deus cortou-a em dois no sentido do comprimento, tendo cruzado as duas medidas uma sobre a outra, fazendo coincidir seus meios, como um X, curvou-as para uni-las em círculo, unindo entre elas as extremidades no ponto oposto à sua interseção $(36$ b-c). 
Eis a nota de Godwin:

A escala diatônica é agora imaginada como disposta sobre uma tira de pergaminho. A tira é dobrada de forma a que suas extremidades se encontrem, e, então, o comprimento da resultante tira circular é cortado em dois. Os dois círculos são girados um em relação ao outro até o ponto de terem, vistos de lado, a forma de um X (Godwin, 1990, p. 405).

Enfatizemos as palavras de Godwin colocando-as em contraponto com o destacado sentido do referido corte em dois de toda esta composição ("imaginada como disposta sobre uma tira de pergaminho"), sentido que o passo platônico diz textualmente ser longitudinal ("no sentido do comprimento"). Como Godwin deduz corretamente que a mencionada composição se trata da escala diatônica, então, o corte em sentido de comprimento é um corte que perpassa longitudinalmente a totalidade desta escala, duplicando-a, de certa forma. A escala, por tal corte, foi duplicada na forma de dois segmentos (duas escalas, portanto) os quais foram intersectados de forma a fazer "coincidir seus meios" ${ }^{17}$. Caber-nos-ia, então, perguntar que meios (o ponto de intersecção) destas duas escalas são estes.

O primeiro passo para uma resposta é não perder de vista que, nos termos platônicos, as grandes medidas, tal como a da dissonância máxima do trítono e do tirano (729), são as que representam, ao contrário daquelas mais próximas da unidade, as maiores distâncias ou afastamentos da principialidade ontológica. Tendo este em mente, o segundo é o quanto a figura resultante, à luz do vínculo entre a ciência da harmonia e a astronomia, insinua os princípios constitutivos da esfera armilar, o que faz com que os dois círculos entrelaçados configurem a eclíptica, entre outros apontada por Lippman (1975, p. 24), ou seja, o entrecruzamento da esfera celeste e da equatorial. Dessa forma, o ponto central do referido $\mathrm{X}$, configurado por uma especial perspectiva deste entrelaçamento, é uma visão de uma das pontas extremas do eixo que une os dois equinócios em único ponto, um ponto espacialmente referencial que, por ser determinado pela posição unívoca do sol, deve ser entendido como sendo 1:1, a fundamental da escala diatônica. Conseqüentemente, se o entrecruzamento equinocial nos apresenta a fundamental da escala, o uníssono para um pólo e o eqüíssono para aquele gerado pela união "das extremidades no ponto oposto à sua intersecção", já os pontos que configuram a maior divergência no entrelaçamento das duas esferas, exatamente aqueles que são caracterizados 
pelas mudanças extremas da posição do sol, os solsticiais, configuram aquelas versões do trítono entre as quais subsiste a diferença irredutível da coma pitagórica, ou seja, 531441:524288, a diferença entre 1024:729, a versão para a escala descendente, e 729:512, a para a ascendente.

Passando diretamente dos princípios da ciência da harmonia para o modelo geocêntrico da astronomia tradicional, em consonância com o elo entre estas duas ciências, o passo do Timeu continua nos seguintes termos:

Envolveu-as com o movimento uniforme que gira no mesmo lugar, e, dos dois círculos, fez um exterior e outro interior. O movimento do círculo exterior, designou-o como sendo o movimento da natureza do mesmo; o do círculo interior, como o da natureza do outro. Fez girar o movimento do Mesmo pelo lado e para a direita, o do Outro, por sua vez, pela diagonal e para a esquerda. E deu proeminência à revolução do mesmo e semelhante, pois só a ele toleraria sem divisão. Por sua vez, tendo dividido seis vezes o movimento interior, fez sete círculos desiguais, segundo os intervalos duplos e triplos, um por um, de tal maneira que houve três de cada espécie. Ordenou a esses círculos moverem-se em sentidos contrários uns aos outros, três semelhantes pela velocidade, e quatro, com velocidades diferentes entre si, e estas, das três primeiras, mas conduzidos conforme uma razão (36 c-d).

Sem maiores explicações, Platão implica, na totalidade deste passo do Timeu, as sete porções da lámbda que entrelaçam os duplos e os triplos, e as sete esferas planetárias advindas das seis divisões do círculo de alteridade. Proclo entende que estas sete partes correspondem aos sete tipos de razões, respectivamente: igual, múltipla, submúltipla, superparticular, subsuperparticular, superpartiente e subsuperpartiente. Estas podem ser sintetizadas triadicamente em razões de igualdade, de maior desigualdade e de menor desigualdade - ou tetradicamente, uma vez que as seis que subseqüenciam as de igualdade articulam três pares de reciprocidade, os quais, quando somados com a primeira, compõem um conjunto de quatro. Proclo vê esta última ordenação, quaternária, como uma tetraktýs, e a estrutura desta sua analogia é a seguinte: a razão de igualdade (1:1, 2:2, etc.) é sempre um, ou seja, é sempre monádica e, portanto, equivale ao ponto; a múltipla e a submúltipla, fundamentalmente diádicas, correspondem à linha, que compreende a monadicidade do ponto; a superparticular e a subsuperparticular, triádicas, mantêm uma conecção perfeita com o plano, o 
qual abrange a unilateralidade da linha; e a superpartiente e a sua recíproca, tetrádicas, são análogas ao nível concrescional do sólido, que, ao tridimensionalizar o plano, compreende todos os níveis anteriores.

Retornando ao "X" da questão, é um tanto evidente que, no passo do Timeu, está sendo proposta uma associação do círculo do Mesmo, o único tolerado sem divisão, com a imutável esfera das estrelas fixas, enquanto que os sete anéis, advindos das seis divisões do círculo da alteridade - o campo da divisibilidade -, correspondem às esferas planetárias, envolvidas pela primeira. Temos aqui mais um elemento fundamental das matemáticas tradicionais que o platonismo herda e transmite: o das duas formas de comunhão cosmogônica, expressas respectivamente pela multiplicação e adição, de dois princípios que, enquanto Platão representava por, a aritmosofia pitagórica entendia ser o 3 e o 4, vale dizer, o triplo primordial, caracterizando a idealidade da totalidade tripla, e a tétrade, um duplo que retrata os estágios de uma gradativa concretude e, portanto, multifacetação do todo, como vimos a propósito da última tetraktýs proposta por Proclo.

A primeira de tais formas de comunhão, a multiplicação $(3 \times 4)$, com a indiscutível abrangência atestada por ser uma operação de consecutivas adições de um mesmo número, produz o 12 , resultado que simboliza a perfeição do círculo e da imutabilidade do movimento uniforme que gira sem sair do lugar, vale dizer, da eviternidade do céu das estrelas fixas cuja angularidade se modalizará pela atividade planetária das sete esferas advindas das seis divisões do círculo da alteridade. Estas, que resultam da segunda forma de comunhão, a adição $(3+4)$, efetivam a profícua divisibilidade que encontra, no seio de uma indefinida variabilidade, marcos exemplares tipificados, pelo simbolismo geométrico dos ângulos, na forma dos aspectos astronômicos de conjunção, oposição, trígono, quadrado e sextil, de cada um com qualquer outro dos sete. Neste passo do Timeu, Platão não deixa de evidenciar, para as sete esferas planetárias, o fundamento da adição de 4 e 3 quando, a despeito da aparente desarmonia da disparidade de seus movimentos diferentes e por vezes contrários, enfatiza, porém, no que tange às velocidades, a configuração de dois grupos, um de três e outro de quatro: Sol, Mercúrio e Vênus são planetas de velocidades semelhantes, enquanto os quatro restantes têm velocidades dissemelhantes entre si e em relação às três esferas planetárias anteriores, embora de acordo com relações regulares, o que faz das referidas discordâncias o suporte de harmonias mais profundas.

Sob o ponto de vista da teoria astronômica tradicional, as órbitas planetárias presentificam porções de tempo em sucessivos encadeamentos, cuja totalidade ordenada é uma representação da eternidade (Timeu 37 c-d) ${ }^{18}$. A analogia 
entre tais corpos em movimentos regulares e periódicos e a ciência da harmonia era matematicamente irresistível e factualmente comprovável - uma analogia mantida em prática até Kepler. Desta forma, as proporções dos encadeamentos das porções de tempo engendrado, representando o tempo não-engendrado, eram vistas como diretamente relacionadas com as parcelas de sons contidos em um som fundamental pelas divisões proporcionais de uma corda musical.

Vemos, portanto, que a música traduz, tanto no plano empírico e microescalar - as relações númericas subjacentes à corda musical - quanto no da pura especulação dianoética, os princípios que se manifestam nas macroescalas dos corpos celestes. Para os estudantes, mesmo os mais principiantes, de música, uma das mais fundamentais conexões com a teoria da harmonia já pode ser encontrada no fato de que os números $12(3 \times 4)$ e $7(3+4)$, cuja importância para a astronomia tradicional se assenta na representação da esfera zoodiacal e as esferas planetárias, se fazem presentes, com todas as proporções numéricas aí implicadas, na relação entre a estrutura dodenária da escala cromática e a setenária da diatônica, além dos exaustivamente abordados círculo de 12 quintas e de 7 oitavas. Não é difícil, em consonância com os antigos, concluir, junto com Cláudio Ptolomeu, entre muitos outros que poderíamos citar, que "o poder dos princípios da harmonia habita dentro de todas as coisas que atingem, por natureza, uma completude, e manifesta-se mais claramente na alma humana e no movimento das estrelas" (grifos nossos), conclusão demonstrada no estudo de harmonia deste conceituadíssimo astrônomo alexandrino do séc. II d. C. de quem já tanto falamos a propósito da afinação, musical e celeste, sintônico-diatônica (Godwin, 1993, p. 24).

Para o leitor famliarizado com os ditames da teoria da harmonia tradicional, é evidente que obras tais como os dois diálogos aqui mais enfocados, Timeu e República, fundamentam seus respectivos ápices cosmológicos, atingidos pelas explanações das configurações astronômicas do cosmos, na disciplina matemática da música, sempre em obediência à proporção de que esta está para a astronomia de forma análoga ao encaminhamento pelo qual o princípio antecedente se dirige para sua conseqüente manifestação. Tal proporção plenifica-se quando nos damos conta de uma das raras, e por isso mesmo marcante, explicitação presente em vários diálogos platônicos e escandalizada na República: a articulação tetrádica das ciências matemáticas, na qual a rítmica do encaminhamento que leva a música a ser corporificada na astronomia é antecedida por aquele que faz a aritmética espacializar-se na geometria (Rep. VII 525 a - 531 d). Assim, aritmética, música, geometria e astronomia, sem mencionar a intermediação, proposta tanto na República quanto no Timeu, da estereometria entre as duas últimas, 
ordenam-se de forma a retratar os estágios que perpassam a principialidade do número, sua polarização temporal (tempo e número) e espacial (espaço e número), todos estes reunidos nos movimentos dos corpos celestes (espaço, tempo e número).

A propósito de uma das colocações sobrecitadas de Aristóteles da função transcedente, diferentemente da metafísica da imanência dos pitagóricos, que Platão preconizava para o estudo destas ciências numéricas como instrumento para o conhecimento das coisas (Metafísica i 6; 987 b 22), vale dizer, das causas ou seres, recordemos que tal estudo, ao visar a uma contemplação dianoética, paradigmática ou inteligível, do cosmos, constituia uma indispensável preparação para a contemplação eidético-noética das realidades intelectivas ou metacósmicas. A importância desta justa e necessária preparação pode ser vislumbrada nas palavras de Platão, ou de seu escriba Felipe, no Epinomís:

Para aquele que se instrui adequadamente, todos os diagramas e sistemas numéricos [geometria e aritmética], assim como todas as composições harmônicas e revoluções siderais [música e astronomia] devem revelar a comum unidade de todos, e desvelar-se-á se, como dissemos, nos instruirmos corretamente, dirigindo nosso olhar para o um. Pois para os que meditam, um único vínculo natural a todos revelar-se-á (991e-992a).

Estas quatro vias, que viriam a ser denominadas de quadrivium já encontravam plena explanação pitagórica quase um século antes de Platão. Na transcorrência de dois milênios permeados por uma tradição ininterrupta, ou seja, desde os pitagóricos pré-platônicos até Zarlino, cosmomusicólogo do final da Renascença, permaneceu intacta a estipulação das duas instâncias: a mais principial que reunia a aritmética e a música, ou seja, a quantidade discreta de per si e a quantidade discreta em relação, antecedendo, ontológica e cosmologicamente, à instância que reunia as ciências que manifestavam tais princípios na forma da quantidade contínua imóvel e da quantidade contínua móvel, respectivamente a geometria e a astronomia. Dessa forma, as relações dadas entre as ciências principiais e as manifestas foram articuladas, como vimos acima, em uma única relação de duas relações, ou seja, em uma proporção pela qual se entendia que a aritmética está para a geometria assim como a música está para a astronomia.

Kepler, no início do séc. XVII, foi o primeiro, em sintonia com a cabal mudança de era que nesse momento se dava, a necessitar reagrupá-las. Em prol 
de encontrar as razões que ele entendia como necessárias para fundamentar as consonâncias, sempre pressupostas como consonâncias cósmicas pela musicologia tradicional, retirou a ciência da harmonia, a música, do orbe das quantidades discretas, orbe no qual a aritmética passaria a reinar sozinha, para colocá-la no das quantidades contínuas, mais especificamente entre a geometria e a astronomia (Cohen, 1984, p. 13-43). A possibilidade deste trânsito, cujos resultados provaram ser muito bem sucedida, de uma instância principial para a das configurações de maior teor analógico com o mundo sensível, pode ser vista como mais uma prova do papel nuclear da ciência da música, o papel realizador da transmutação recíproca do inteligível no sensível e vice-versa, por intermediar o tempo manifesto onde impera a continuidade e o tempo discreto pautado pela descontinuidade. Eis uma das mais altas funções da ciência da música ou teoria da harmonia.

\section{Notas}

* Mestrando em Música pelo Programa de Pós-Graduação da UNESP de São Paulo e Professor do Curso de Música da FAAM.

1 Uma vez que a concepção de música enquanto elaboração artesanal nasceu, como não poderia deixar de ser, junto com o despontar dos primórdios da escritura musical - esboçada embrionariamente a partir do séc. XI d.C. para somente atingir um grau de maturação no final do período medieval -, fá-se necessária a ressalva de que a categoria da música instrumental, em termos da tradição platônica, se restringia apenas à utilização do instrumento denominado monocórdio, o qual, através das divisões regulares de uma corda sonora, torna audível, dentro do campo de suas limitações, parte da abordagem dianoética inaudível das harmonias numéricas nos termos pura e infalivelmente matemáticos da ciência musical.

2 A tripartição que estamos apontando na música é um procedimento generalizável a todas outras ciências. Assim, também na aritmética, três conceitos fundamentais de número fundamentam sua tradicional tripartição. Ghyka, citando Nicômaco, começa por dois deles: o número divino, ou número-idéia, e o número científico. O primeiro é tema de uma aritmologia de tendências metafísicas, a parte mais elevada da aritmética, dirigida exclusivamente aos filósofos. O segundo, tendo o anterior como modelo ideal, é a ocupação da aritmética propriamente dita, uma parte intermédia ainda dirigida aos então iniciados, obedecendo um método silogístico rigoroso de tipo euclidiano. Já a parte inferior e funcional-operativa da aritmética, a logística ou cálculo, é uma técnica para comerciantes que opera com os números concretos (Ghyka, 1978, p. 22).

3 São elas: limite e ilimitado, ímpar e par, unidade e pluralidade, direita e esquerda, masculino e feminino, repouso e movimento, reto e curvo, luz e obscuridade, bem e mal, e quadrado e retangular. 
4 Ou seja, o procedimento de "conciliar o inconciliável" a partir do estabelecimento de vínculos intermediários entre os termos ou coisas opostas, o que em linguagem musical significa produzir uma consonância através da resolução abrangente de uma dissonância que, por sua vez, fundamenta a primeira e se mantém sempre irremediável no seu próprio nível.

5 Comparando este tipo de erro ao seus correpondentes nas outras ciências - a astronomia, por exemplo - Platão entende que o estudo da harmonia deve ocorrer em termos exclusivamente matemáticos. $\mathrm{Na}$ seqüência desta mesma passagem ele afirma: "Eles também buscam os números nestes mesmos acordes que escutam, mas não perscrutam os problemas nem consideram, portanto, quais números são harmônicos e quais não, e por que são assim uns e outros" [531 c]. Aprisionar-se nas referências sensíveis, nas exatas palavras de Platão, "não só resulta ineficaz, senão ridículo". Especificando tal ineficiência e ridículo, assim ele continua: "Referem-se [tais músicos] a uma certa combinação e lançam os ouvidos ao longe, como se quisessem capturar os sons da casa do vizinho. E uns dizem que ainda podem ouvir mais um som no meio, que então viria a ser o menor intervalo possível, pelo qual se pode efetuar a medição; enquanto outros, pelo contrário, afirmam que os dois sons [entre os quais os primeiros sentem a possibilidade de inserir um ao meio] são claramente semelhantes. Pois bem: ambos inclinamse mais à audição do que à intelecção" [531 a].

6 Proclo, a este propósito, afirma: "Ninguém, portanto, deveria estacionar na teoria matemática, mas, sim, deveria excitar a si mesmo a um modo de investigação [verdadeiramente uma 'in-speção'] adaptada à essencia da alma; nem mesmo se deveria pensar que devemos direcionar nossa atenção para intervalos ou para a diferença de movimentos. Pois estes são pressupostos, e não são de modo algum convenientes aos temas de investigação propostos. Porém, o que se deveria fazer é observar as afirmações em si mesmas, e considerar como elas proporcionam uma indicação do meio psíquico e, então, procurar pela providência demiúrgica enquanto finalidade última delas" (Proclus, 1990, p. 75).

7 Como pode ser justificadamente difícil para o leitor localizar específicamente este tema (os subseqüentes são mais auto-evidentes) neste livro da República, para além de sua presença implícita por diversificadas analogias, destacaremos o passo de sua explicitação, a saber, o 337 a-b.

8 Observe-se que o encadeamento indefinido da série das razões superparticulares (3:2, $4: 3,5: 4,6: 5$, etc.) não cessa de apontar para o "último" termo, o inatingível 1 , unidade teleologicamente prometida e nunca alcançada como um dos termos da e na referida série. Já o encadeamento das razões subsuperparticulares (2:3, 3:4, 4:5, 5:6, etc.), também suspiram nostalgicamente por um retorno à unidade, da qual gradativamente se aproximam sem nunca poderem efetivamente realizá-la. Por estarem aquém da unidade enquanto um todo, transcorrem pela diminuição da diferença em relação a este todo e, então, progridem por gradativos acréscimos em direção à completude da unidade, inatingível no mesmo plano desta progressão.

9 Ousaríamos afirmar que o demiurgo divide enquanto harmoniza e harmoniza enquanto divide. Proclo vê como evidência da integração destas duas operações o próprio setenário, mais propriamente duas facetas opostas e complementares deste, facetas 
contidas na providência demiúrgica. "Pois a hebdômada", divisão periodológica em sete, "é um número comum a estas ambas divindades, uma vez que os teólogos também afirmam que Baco foi dividido em sete partes. (...). E eles atribuem a héptada a Apolo, como contendo todas as sinfonias. Pois a dupla diapasôn", a oitava dupla (4:1), "subsiste na mônada, na díada e na tétrada, números dos quais a hebdômada consiste", referindo-se à progressão dupla 1:2:4, a dupla oitava, de onde decorre o setenário, pois $1+2+4=7$. "Então eles chamam tal deus de 'nascido no sétimo dia', e afirmam que este dia é a ele consagrado". Proclo afirma que esta bidimensão do setenário é comunicada à alma por estas duas divindades, Apolo e Dioniso, de forma que, de um lado, "por uma divisão em sete partes, a alma possa ter uma signatura da série dionisíaca", e do outro, "possua, porém, harmonia nestas partes, como um símbolo da ordem apolínea". "Pois na laceração de Baco, é Apolo quem recolhe e une as partes distribuídas de Baco, segundo a vontade do pai (Zeus)” (Proclus, 1990, p. 77).

10 Temos então, como nos mostra Brumbaugh (1989, p. 20-4), uma estrutura cujo esquema é uma escala ascensional de quatro grandes temas (a-b-c-d), o ápice do tema central $(F)$ e a descida dos temas extremos correspondentes escalonados (d-c-b-a) que podemos encontrar sintetizada enquanto pista isomorficamente suficiente dentro da própria República no mito da caverna (Rep. VII 514 a - 518 b). Tal estrutura especular é sintetizada no próprio tema central (F) onde recai o espelho, onde a dupla direcionalidade vertical, da gradual saída da e entrada na caverna, tem como vértice exatamente a contemplação direta dos "objetos" eidético-noéticos à luz do sol inteligível.

11 Ao nosso ver, Platão desenha um duplo espelho simultâneo, como aquele que inverte todas as direções espaciais, o espelhamento ótico, quando uma imagem é refletida na retina. Duplo porque, se fossemos representá-lo bidimensionalmente, ele seria um espelhamento horizontal de um vertical (ou um vertical de um horizontal), ou, segundo os ditames da teoria musical, um retrógrado da inversão. Este tipo de espelho é típico da arte e da ciência musical, mas, porque musicalmente tal estrutura transcorre na sucessividade do tempo - e, de certa forma, nele se vela enquanto se desvela -, sua apreensão, na simultaneidade do espaço, é somente esquematizável geometricamente, desvelando-a enquanto a vela.

12 Aqui, Tomas Taylor, na sua tradução desta obra de Proclo, observa que quando, em uma proporção aritmética, adicionamos aos três números nela envolvidos um quarto número, de forma a produzir, por tal inserção, uma proporção geométrica -ou seja, com os dois pares de números expressando a mesma proporção geométrica-, então tal proporção compreenderá tanto aquela que é aritmética quanto a que é harmônica. Assim, se para os termos 1, 2, 3, um quarto termo, 6, é adicionado - de forma que 1 está para 2 na mesma proporção que 3 para 6 (uma proporção geométrica) - então, na medida em que esta proporção geométrica foi gerada pelo termo que foi adicionado, as outras duas, a aritmética e a harmônica, estão nela contidas, pois 1, 2, 3, são termos que estão na aritmética, e 2, 3, 6, na harmônica (Godwin, 1990, p. 429).

13 Então, para fá, 2:3, à direita de dó, 1, a multiplicação por dois o elevará uma oitava, transformando-o em 4:3, a média harmônica entre 1 e 2 . Recordemos que a razão 
subjacente à diferença entre as duas médias, 3:2 e 4:3, é um tom inteiro, 9:8, um e um oitavo (ou seja, $3: 2$ é 9:8 de 4:3, pois 3:2/4:3=3:2 X 3:4=9:8). Ré, 9:4, um tom inteiro de dó 2 (a segunda linha pontilhada) - pois $(9: 4) / 2=9: 8$ - deve ser dividido por dois, resultando, então em 9:8, exatamente um tom inteiro de dó 1. Lá, 27:8, quando dividido por 2, descende uma oitava e transforma-se em 27:16 de 1, compondo com 3:2, sol, que ele subseqüencia, um tom inteiro, 9:8, pois 3:2 X 9:8 = 27:16. $\mathrm{Mi}, 81: 16$, para ingressar a posição de terceira nota da escala ascensional de dó, necessita descender duas oitavas e, portanto, ser dividido por quatro, resultando então em 81:64, 9:8 de 9:8 ou $(9: 8)^{2}$, um tom inteiro do tom inteiro de 1, dó. E, finalmente, si, 243:32, para ingressar com a sétima nota da escala de dó, a nota que imediatamente precede o dó2, também necessita ser dividido por quatro, resultando então em 243:128, 9:8 da razão precedente, 27:16, a qual designa, nesta escala, a nota lá.

14 Observe-se que, no parâmetro vertical, retiramos o quarto nível, o mais inferior, entendendo que todos os seres humanos estão assentados no plano básico das aparências sensíveis - eikasía - e que, ao mesmo tempo, ninguém permanece inteiramente nele.

15 Como os próprios exemplos em questão evidenciam, superpartiente é uma razão de maior desigualdade pela qual um número maior (x, por exemplo) contém um número menor (y) uma vez e mais uma parte deste último, desde que tal parte seja maior que $1(\mathrm{x}-\mathrm{y}>1)$. Frente às indefinidas possibilidades pertencentes a esta categoria de razão de maior desigualdade, sua tipificação mais exemplar ocorre naquelas onde o número maior (x), comparado ao menor (y), é o dobro menos a unidade, ou seja, quando $\mathrm{x}=2 \mathrm{y}-1$ (exceptuando a razão de 3:2, na qual a diferença entre as duas quantidades é igual a 1, o que caracteriza um superparticular e não um superpartiente).

16 Pois $80: 80$ ou 81:81 seriam, no plano da quantidade relativa - uma vez que se tratam de razões de igualdade - a identidade perfeita, ou seja, 1.

17 Como pela união das extremidades de cada segmento-escala serão constituídos dois círculos, um envolvendo o outro, e como o círculo envolvente, na seqüência do passo do Timeu, será designado como sendo o da substância do mesmo, e o envolvido como sendo o da do outro, então, frente a tudo o que neste artigo foi apontado em relação à reciprocidade inversa destas duas instâncias, não seria nem um pouco injustificável concluir que as escalas intersectadas se espelham mutuamente e, portanto, se invertem também nos sentidos respectivos, ascensional e descensional.

18 Platão, no Timeu 37 c-d, comenta a passagem crítica da eternidade para a perpetuidade: "Ora, quando o pai que o produziu compreendeu que se movia e vivia, esse mundo, reprodução ornamentada dos deuses eternos, rejubilou-se e, em sua alegria, refletiu sobre os meios de torná-lo ainda mais semelhante a seu modelo. E assim como esse modelo resulta ser um vivente eterno, esforçou-se, na medida de seu poder, por tornar imortal igualmente a esse todo. Ora, é a natureza deste vivente que era eterna, como vimos, e essa eternidade, adaptá-la inteiramente a um mundo engendrado, era impossível. Por isso, preocupou-se em fabricar uma certa imitação móvel da eternidade, e, organizando todo o céu, fez da eternidade una e imóvel, esta imagem eterna de acordo com o número, isso a que chamamos o tempo". 


\section{ReFerênCias Bibliográficas}

BRUMBAUGH, R. S. Platonic Studies of Greek Philosophy: Form, Arts, Gadgets and Hemlock. Albany: State University of New York Press, 1989.

COHEN, H. Quantifying Music: The Science of Music at the First Stage Of the Scientific Revolution, 1580-1650. Dordrecht / Boston / Lancaster: D. Reidel Publishing Company, 1984.

FIDELER, D. Introduction. In: GUTHRIE, J. The Pythagorean Sourcebook and Library. Michigan: Phanes Press, 1988. p. 19-54.

GHYKA, M. C. El Numero de Oro. Traducción por J. Bosh Bousquet. Barcelona: Editorial Posidon, 1978.

GODWIN, J. Harmony of the Spheres: A Sourcebook of the Pythagorean Tradition in Music. Rochester, Vermont: Inner Traditions International, 1993.

GUTHRIE, K. S. The Pythagorean Sourcebook and Library. Michigan: Phanes Press, 1987.

McClAIN, E. G. The Pythagorean Plato: Prelude to the Song Itself. York Beach / Maine: Nicolas-Hays Inc., 1978.

PALISCA, C. V. Scientific Empiricism in Musical Thoughth. In:

Seventeenth Century Science and the Arts. Princeton, New Jersey: Princeton University Prees, 1961. p 91-137.

PLATÓN. Obras Completas. Madrid: Aguilar, 1969.

PROCLUS. Commentary on the Timaeus. In: GODWIN, J. Harmony of the Spheres: A Sourcebook of the Pythagorean Tradition in Music. Rochester / Vermont: Inner Traditions International, 1993. p. 75-85.

RIZEK, Ricardo. The theory of harmony in Plato.

ABSTRACT: I examine some instances of the theory of harmony in Plato. For this purpose, I consider the musical conception and terminology that Plato, at the same time, in herits from the Pythagoreans and passes on to all the many who wrote about music in Greek, such as Proclus, and in Latin, such as Boetius. Ithrow attention to the analogy between auto and the harmonical mean; heteron and the arithmetical mean; the intermediary ousía and the geometric mean. As a result, the way the "intermediary being" makes possible to harmonize the "other" with the "same" is compared to the way the geometric mean harmonizes 
the other means in a numeric series whose intervals correspond to those of the Pythagorean musical scale. In this way, from those "portions" in wich "god" divides the "whole", those that are one to the other as 4 is to 3 correspond to the diatessáron or fourth [harmonical mean]; as 3 is to 2, to the diapénte or fifth [arithmetical mean]. The ratio 256:243 arises, therefore, as the ratio corresponding to theleîmma, i. e., to the díesis or Pythagorean "halftone".

KEYWORDS: geometric, harmonical and arithmetical means; Pythagorean and Ptolemaic musical scales; enkýklios paideía and quadriuium; Timaeus; Plato; Platonism and Neoplatonism. 